\title{
A POSSIBLE MESOARCHAEAN IMPACT STRUCTURE AT SETLAGOLE, NORTH WEST PROVINCE, SOUTH AFRICA: AEROMAGNETIC AND FIELD EVIDENCE
}

\author{
C.R. ANHAEUSSER \\ Economic Geology Research Institute, School of Geosciences, University of the Witwatersrand, Private \\ Bag 3, Wits 2050, South Africa \\ e-mail: carl.anhaeusser@wits.ac.za
}

E. STETTLER

School of Geosciences, University of the Witwatersrand, Private Bag 3, Wits 2050, South Africa, and Department of Geology, University of Pretoria, Pretoria, 0020

e-mail: edgars@wbs.co.za

\section{R.L. GIBSON}

School of Geosciences, University of the Witwatersrand, Private Bag 3, Wits 2050, South Africa e-mail: roger.gibson@wits.ac.za

\section{G.R.J. COOPER}

School of Geosciences, University of the Witwatersrand, Private Bag 3, Wits 2050, South Africa e-mail: gordon.cooper@wits.ac.za

2010 December Geological Society of South Africa

\begin{abstract}
A 25 to $30 \mathrm{~km}$ wide magnetic anomaly within the $>2.79$ Ga granite-greenstone rocks of the northwestern Kaapvaal Craton is spatially associated with megabreccia outcrops near the village of Setlagole in the North West Province, South Africa. The breccia comprises angular to rounded clasts of TTG gneisses, granites and granodiorites, with lesser amounts of amphibolite, calc-silicate rock and banded iron-formation as well as unusual dark grey to black, irregular, centimetre- to decimetre-sized clasts that show evidence of fluidal behaviour and plastic deformation during incorporation into the breccia. The largest clasts reach up to several metres in size. Evidence of fluvial transport is found in rare thin sandy to gritty layers that show crude bedding and upward-fining with layers dipping gently to the northeast. The breccia matrix is highly variable but is dominated by angular mineral clasts (mainly quartz and feldspar, with subsidiary biotite, amphibole and epidote) with interstitial chlorite. The clasts show variable amounts of alteration (saussuritization, sericitization, chloritization of biotite and amphibole). The dark clasts contain angular quartz and feldspar and small biotite fragments in a cryptocrystalline chlorite-dominant matrix. Textures indicate a lower greenschist facies metamorphic overprint. The absence of lava, dolomite or quartzite clasts suggests that the breccia formed prior to the deposition of the Neoarchaean Ventersdorp and Eoproterozoic Transvaal Supergroups, whereas the metamorphic grade indicates that it postdates the ca. 2.79 Ga amphibolite-facies metamorphic peak in the region. This suggests a late Mesoarchaean or early Neoarchaean (ca. 2.79 to $2.71 \mathrm{Ga}$ ) age for the breccia. A similar age is inferred for the magnetic anomaly based on postulated crosscutting dyke ages. Despite a comprehensive search, unequivocal shock-diagnostic microdeformation features have not yet been found in either the breccia or the highly-weathered granitic gneiss outcrops in the central parts of the anomaly. The unusual plastically-deformed dark clasts may represent chloritized mud clasts or impact melt clasts. Geochemical data on these clasts and other components of the megabreccia provide no conclusive support for a meteoritic origin, but the unparalleled composition of the clasts and their high trace element abundances of $\mathrm{Ni}, \mathrm{Cr}, \mathrm{V}, \mathrm{Zn}$ and Co relative to rocks of the Kraaipan granite-greenstone basement, suggests an unusual origin for this matrix material. Given the distinctive nature of the breccia and its proximity to a large circular magnetic anomaly, it is postulated that the megabreccia could represent a mass or debris flow in a marine setting triggered by an impact tsunami or resurge. Subsequent faulting may have led to the preferential preservation of these deposits. This interpretation of the Setlagole megabreccia and geophysical anomaly is evaluated in terms of other possible modes of origin and it is concluded that a meteoritic source best fits the available data.
\end{abstract}

\section{Introduction}

Confirmed meteorite impact structures on the African continent are relatively few in number with only 19 having so far been recorded (www.unb.ca/passc/ImpactDatabase/index.html). Of these, seven have been recognized in southern Africa, with four (namely Vredefort, Morokweng, Tswaing and Kalkkop, Figure 1A) in South Africa (Reimold, 2006).

Advances in the attainment of enhanced regional geophysical data sets and improved satellite imaging techniques (e. g., Grieve, 1987; Garwin et al., 1992; Baker and Phillips, 2008; Khirfan et al., 2008; Prinz, T, 


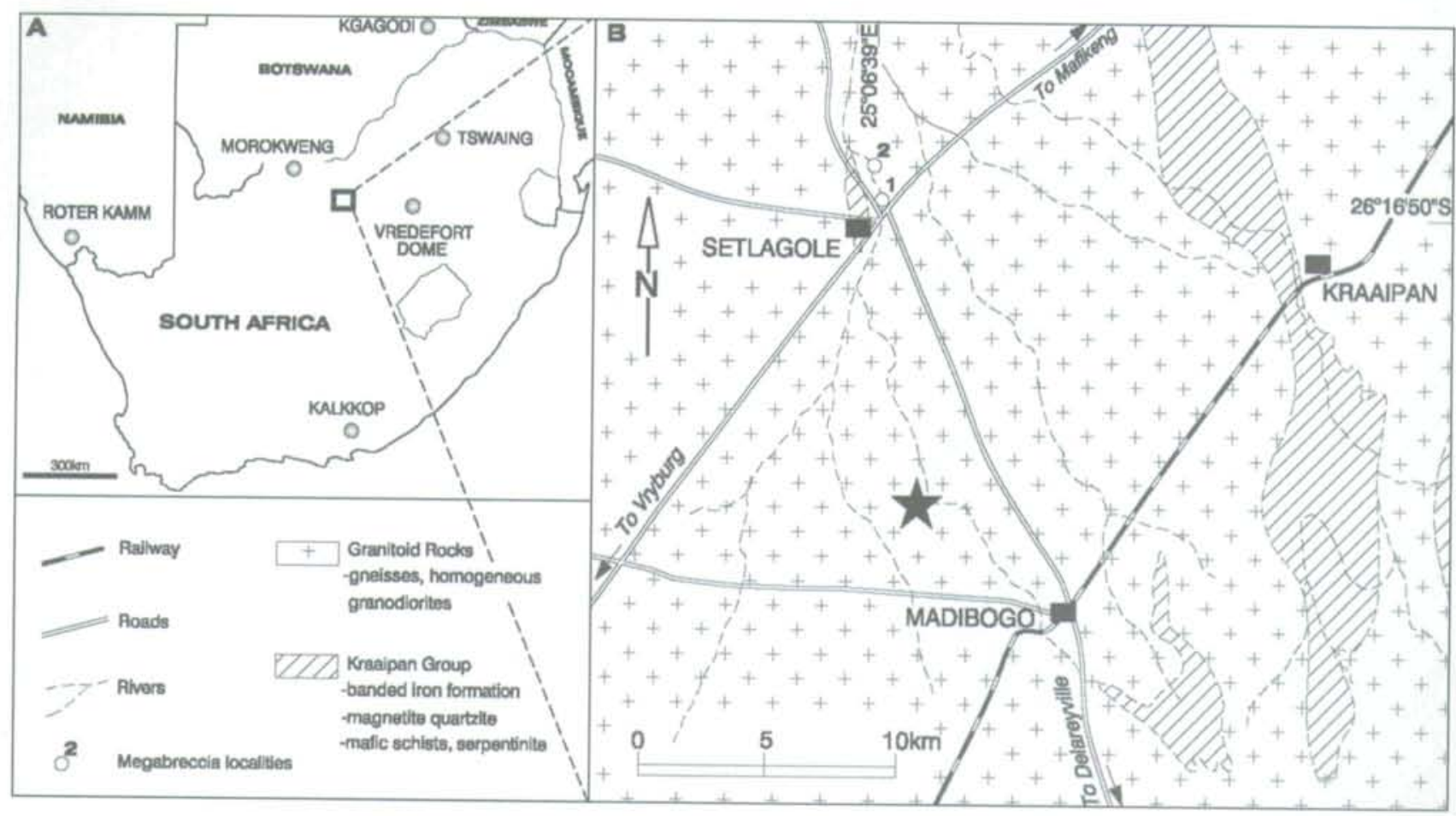

Figure 1. (A) Simplified map of southern Africa sbowing the localities of the confirmed meteorite impact structures in the region and the position of the Setlagole structure reported in tbis paper. (B) Simplified geological map sbous the positions of the centre of the Setlagole structure (star) in the Kraaipan granite-greenstone terrane and the Setlagole megabreccia exposed in tuo meanders in the streambed (localities 1 and 2) immediately north of Setlagole. The area is undertain mainly by Archaean granitoid rocks and scattered greenstone remnants consisting predominantly of amphibolite and banded iron formation.

(30/01/2009, www.uni-muenster.de/GeoPalaeontologie/ Geologie/Ferngis/Gosses_Bluff.html) have resulted in a greater awareness of possible impact features and a number of additional circular structures have been noted for further investigation in southern Africa, particularly in Botswana (Cooper et al., 2010) and Namibia (e.g., Corner, 2008).

A regional aeromagnetic survey undertaken by the South African Council for Geoscience between Mafikeng and Vryburg in the North West Province, South Africa (Figure 1), revealed a 25 to $30 \mathrm{~km}$ wide circular structure in the Archaean granite-greenstone basement of the Kaapvaal Craton approximately $300 \mathrm{~km}$ west of Johannesburg. This basement (referred to as the Kraaipan granite-greenstone terrane), crops out only locally, and comprises upper amphibolite facies banded iron-formation and amphibolite xenoliths up to tens of kilometres long that occur in a variety of massive and gneissic tonalitic, trondhjemitic and granitic (TTG) rocks that range in age from $\mathrm{ca} .3 .16$ to $2.79 \mathrm{Ga}$ (Anhaeusser and Walraven, 1999; Poujol et al., 2002; 2003; Robb et al., 2006). These rocks, which have a dominant northnorthwest strike and steep dips, are unconformably overlain to the east, south and west by subhorizontal lavas of the ca. $2.71 \mathrm{Ga}$ Ventersdorp Supergroup, which are, in turn, overlain to the northeast and southwest by the dolomitic Chuniespoort Group (lower Transvaal Supergroup). Cenozoic Kalahari Group sand and calcrete covers much of the area, with rock exposures confined to stream beds or, in the case of the banded iron-formations, low ridges,

In addition to these rocks, Du Toit (1906) noted two exposures of megabreccia that occur in a stream bed north of the village of Setlagole (Figure 1B). He interpreted the breccia as marking a major thrust fault, although this interpretation could not be subsequently corroborated (Anhaeusser, 1991; Zimmermann, 1994). In this paper we provide a comprehensive field, microscopic and geochemical analysis of the breccias and discuss their possible links to the magnetic anomaly to their south.

\section{Geophysics}

In view of the generally poor exposure of the Kraaipan granite-greenstone basement, and for mineral exploration purposes, high-density aeromagnetic data for the North West Province of South Africa was generated by the Council for Geoscience in the late $1980 \mathrm{~s}$, and was made available on a $200 \mathrm{~m}$ line spacing. These revealed a faint circular anomaly up to $30 \mathrm{~km}$ wide, centred on $25^{\circ} 7.5^{\prime} \mathrm{E}$ and $26^{\circ} 22.5^{\prime} \mathrm{S}$, between the villages of Setlagole and Madibogo (Figure 2).

Figure 4 a shows an image of the raw magnetic data. Filtering techniques, involving horizontal and vertical derivative-based algorithms similar to those described by Cowan and Cooper (2005), have been applied to enhance the magnetic signature of the feature. Space domain high-pass filtered data, shown in Figure $4 \mathrm{~b}$, 


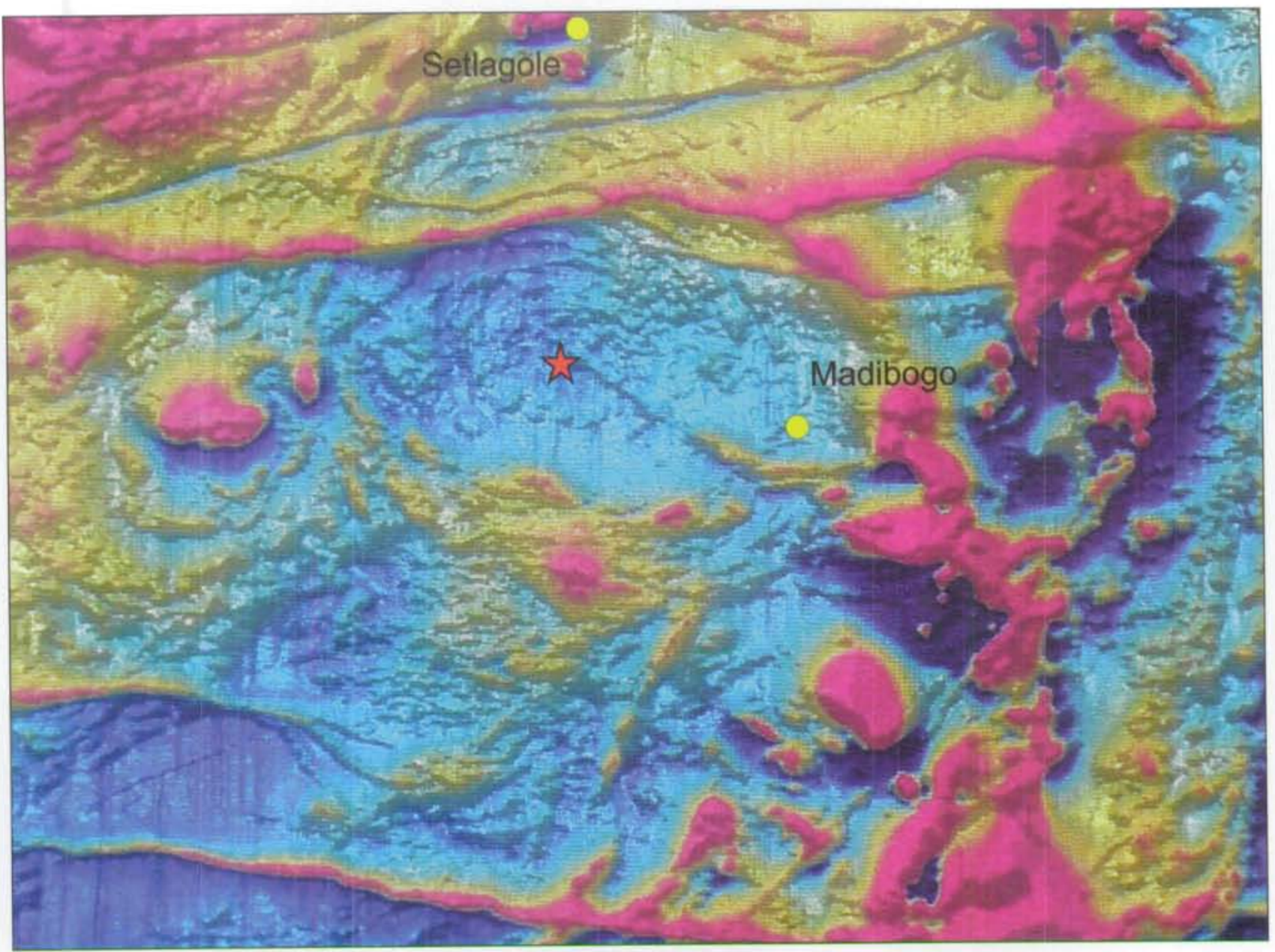

Figure 2. Aeromagnetic image of the Setlagole-Madibogo area sbowing a circular anomaly and cross-cutting lineaments interpreted as dykes. The warm colours reflect magnetite-rich rocks, including the Archaean Kraaipan iron formations. The terrane dominated by the cooler colours is underlain mainly by Archaean granitoid rocks. The star marks the centre of the structure and the megabreccia outcrops lie just off the image immediately north of Setlagole. The distance between Setlagole and Madibogo is $18 \mathrm{~km}$.

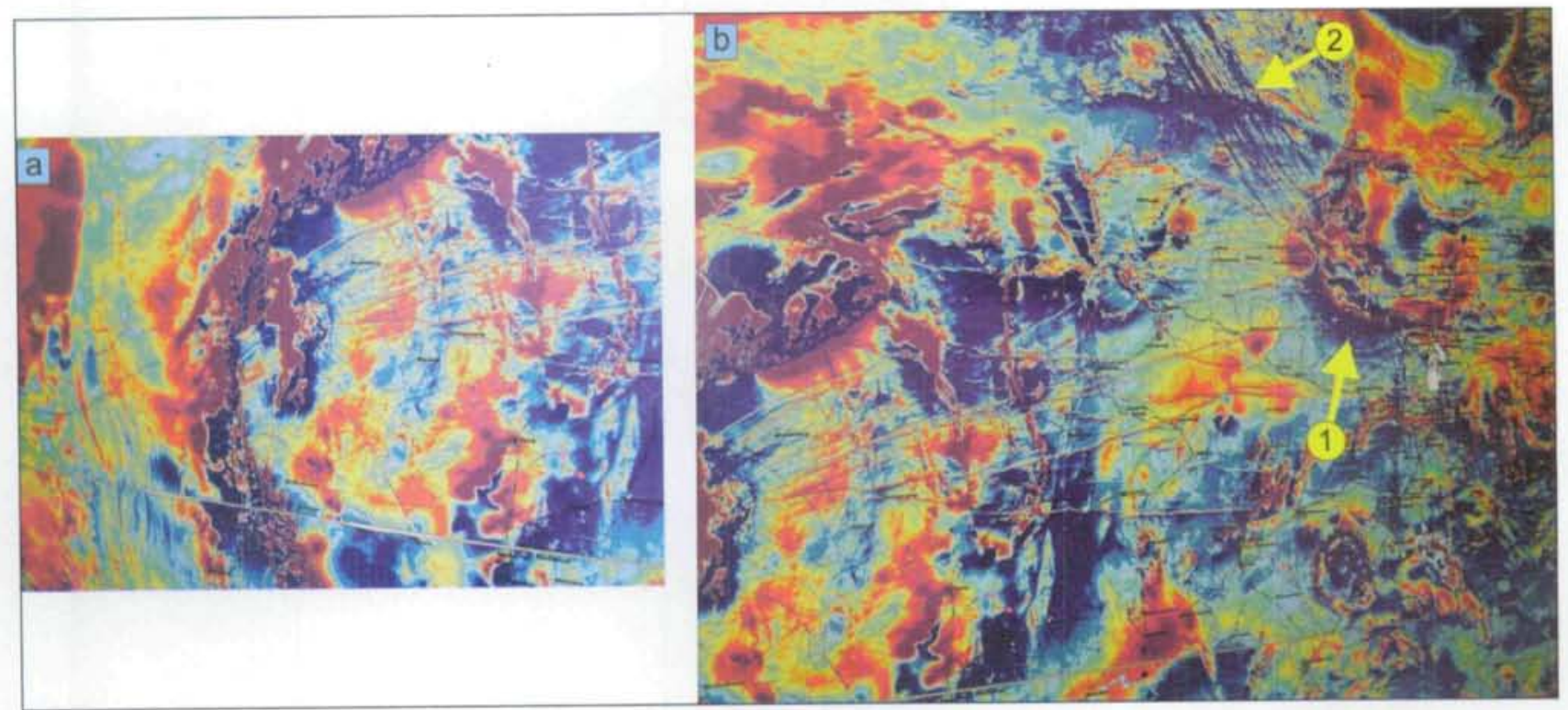

Figure 3. Aeromagnetic maps of the west-central Kaapvaal Craton sbowing (a) the east-nortbeasterly-trending dykes, wbicb are truncated by the north to south trending ca. 1.93 Ga Olifantshoek Supergnoup formations in the far west; and (b) the same dykes truncated in the east by the ca. 2.06 Ga Busbueld Complex (arrow 1). Nortbwesterly-trending Pilanesberg dykes, ca. 1.31 Ga in age, are also shown (arrow 2). Aeromagnetic images after Reed (1996). 
sharpens all anomalies at the cost of increasing the noise in the result. Figure $4 \mathrm{c}$ shows a tilt-angle image (basically an amplitude-normalized 1st vertical derivative) following the method of Miller and Singh (1994). The fourth image (Figure 4d) applies radial sunshading (Cooper, 2003), which enhances circular features of any radius around a chosen centre location.

The data reveal a faint circular magnetic anomaly with a $7 \mathrm{~km}$-wide central core surrounded by discontinuous curved semi-concentric lineaments (Figures 2, 4 and 5). The strongly circular core contains a number of faint curved, semi-concentric, magnetic lineaments in its northeastern quarter. A northweststriking lineament partially subdivides the core into northeastern and southwestern segments.

The surrounding concentric band is not symmetric around the core. The outer perimeter of the band appears to be defined by a slightly elliptical ring of strong magnetic anomalies of an unknown rock, which we speculate may be Kraaipan banded iron formation. At its widest, the band is between 25 and $30 \mathrm{~km}$ in diameter. In the south, the perimeter, as shown in Figure 5 , is highly speculative, which we attribute to a partial cover of Ventersdorp Supergroup lava extending east-northeast towards Madibogo (Figure $4 \mathrm{c}$ and d). The band exhibits a number of faint semi-concentric magnetic lineaments that are best developed in the northern and northeastern sectors (Figures $4 \mathrm{c}$, $\mathrm{d}$ and 5).

Figure 6 shows a profile of magnetic values extracted along a west-southwest to east-northeast traverse (A-A', Figure 5). The edge of the feature is marked by a clear magnetic anomaly, which has a larger amplitude in the east than in the west. The core and outer band of the postulated structure are at a slightly lower magnetization than the granitic rocks outside the structure. A possible model using only the Earth's present direction of magnetization as inducing vector is also shown in Figure 6. According to this model, the material forming the rim of the collar dips shallowly ( $20^{\circ}$ and less) to the east for both the western and eastern rims. Since a good fit cannot be obtained between the calculated magnetic field of the model and the observed field, this model has to be treated with caution and it is expected that the rocks underlying the core and outer band have a substantial remanent magnetic field component. This requires further investigation.

A number of strong linear magnetic anomalies cross the structure and adjacent terrane (Figures 2 to 5). Although no ground-truthing has been possible owing to the general lack of outcrop, these are interpreted as dykes, with or without fault movement (see Discussion). Based on cross-cutting relations seen in Figures 2 to 5 , and using correlations with regional lineaments and dyke patterns (Figure 3), at least three possible ages of lineaments and dykes may be present. The apparently oldest lineament/dyke variety (indicated by dots in Figure 5), trends west-southwest to east-northeast and splits in two on the northern rim of the anomaly. This orientation is parallel to the major structural grain of the
Kaapvaal Craton, which includes the ThabazimbiMurchison Lineament. The lineament has an unusual magnetic pattern, which consists of a strong negative anomaly that probably reflects a strong remanent magnetic component. Where it is intersected by the youngest dykes (northern boundary of the map in Figure 5) this negative pattern is broken up, indicating its older age. The magnetic pattern resembles that of socalled 'negative' (reversely magnetized) northwest to southeast striking Pilanesberg dykes (ca 1.45 to $1.2 \mathrm{Ga}$ old; Van Niekerk, 1962; Harmer, 1992) that occur $100 \mathrm{~km}$ further to the northeast (Figure $3 \mathrm{~b}$ ). These are normally composite dykes consisting of diabase, syenite and nepheline syenite (Verwoerd, 2006); however, no Pilanesberg-type dykes have been reported this far west.

A second west-southwesterly-trending dyke (solid line in Figure 5) occurs closer to the centre of the circular anomaly. Its relationship to the northern dyke is not clear; however, it can be followed for over $200 \mathrm{~km}$ eastwards (Figure 3b) and appears to represent a preKaroo (and possibly post-Transvaal) diabase (Keyser, 1998). This dyke is intersected by a younger, westnorthwesterly-trending dyke (broken line pattern in Figure 5), This dyke is more irregular, reflecting intrusion associated with Riedl fracturing, and possible exploitation of the banded iron formation-granitoid rock contact along the eastern rim of the circular anomaly. Together with a second dyke to the northwest (Figure 5), this dyke shows a high-low magnetic pair with the high over its northern edge. This pattern is consistent with dolerite of post-Karoo age.

The feature responsible for the circular geophysical anomaly thus appears to be older than all the dyke varieties recorded in the North West Province. The implications for the possible age of the circular structure are discussed later.

\section{Field observations}

Outcrop within the area covered by the SetlagoleMadibogo magnetic anomaly is extremely poor and is restricted to a few highly weathered outcrops in stream beds that cut into the sand and calcrete cover. No outcrop was found in the area covered by the central core of the anomaly. Outcrops in the stream bed between Setlagole and Madibogo (Figures $1 \mathrm{~b}$ and 2) comprise variably fractured leucogranite and granitegneiss (Figure 7). Comparison with other outcrops in the Kraaipan region suggests that these rocks are more strongly fractured. Locally intense fracturing has led to brecciation, with quartz, epidote and chlorite filling. Similar easterly-striking subvertical fractures cut the breccia north of Setlagole.

Towards Setlagole, east-northeasterly-trending banded iron-formation and subsidiary amphibolite crop out to the west and south of the breccia outcrops (see Figure 5). Two megabreccia outcrops are found approximately $2 \mathrm{~km}$ apart in meanders of the Setlagole River (Figures $1 \mathrm{~b}$ and 8). A poorly-exposed basal contact of the megabreccia with amphibolite is found on the 

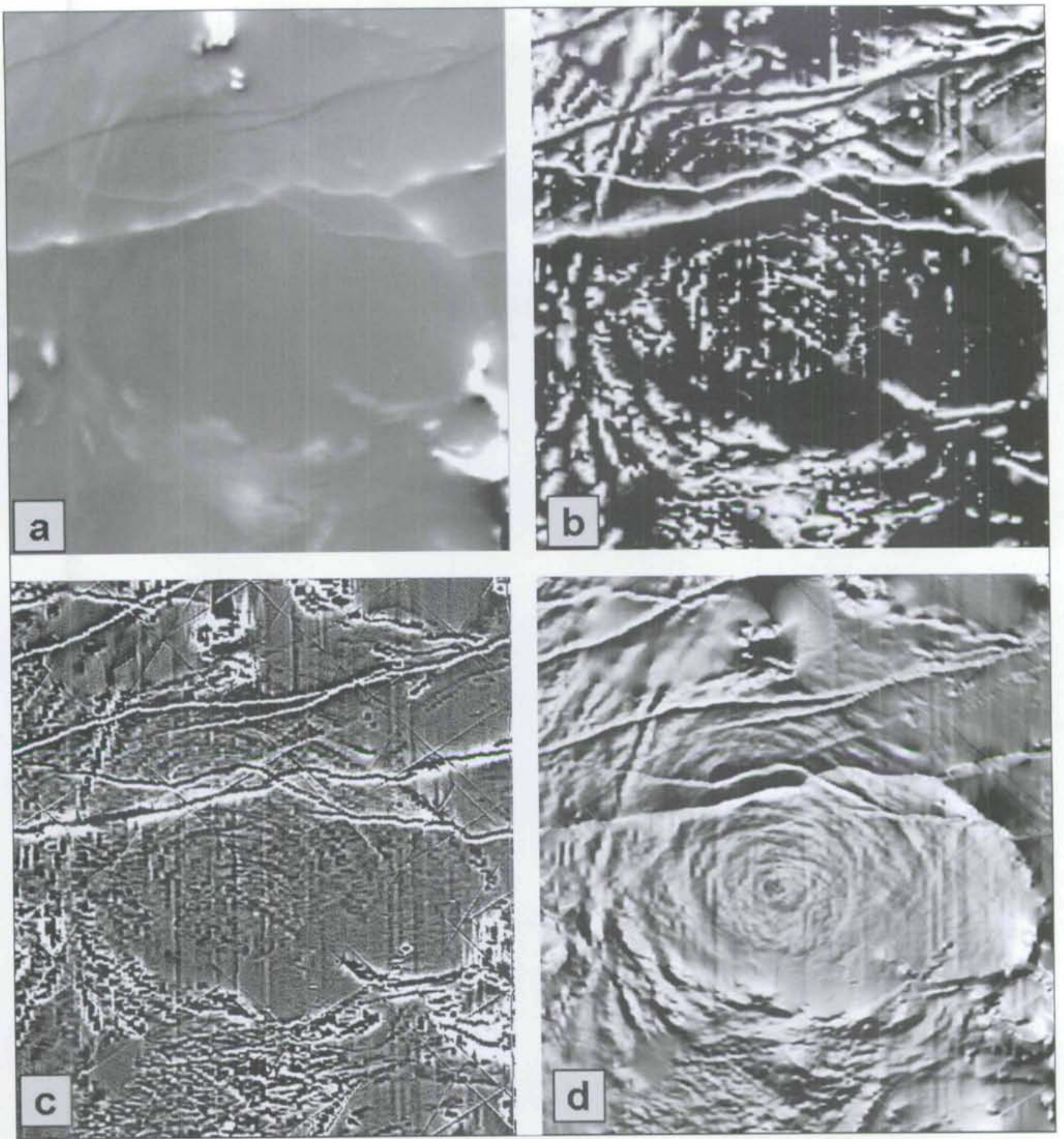

Figure 4. Aeromagnetic data images of the Sellagole-Madibogo area enbanced using filtering techniques. (a) Image of the raw magnetic data. (b) Space domain bigb-pass filtered data (metbod after Cowan and Cooper, 2005), wbicb sharpens all anomalies. (c) Tilt-angle image following the method of Miller and Singb (1994). (d) Radial sun-sbaded image, after the metbod of Cooper (2003), which enbances circular features (see text)

southern side of the southern outcrop (Locality 1), otherwise no contact relationships are discerned. A general northward dip of the basal contact suggested by this relationship is consistent with evidence of bedding (see below) that dips gently $\left(\sim 10^{\circ}\right)$ to the northeast in the northern outcrop (Locality 2 ). Assuming no fault disruption, this could imply a breccia thickness of several hundred metres; however, the presence of easterly-trending fractures cutting the breccias may mean that the breccias are disrupted by faults (see Discussion). The maximum vertical section exposed in each outcrop is $<10 \mathrm{~m}$.

The megabreccia comprises clasts of rounded to angular granitic and gneissic TTG lithologies that range up to a maximum size of $6.5 \mathrm{~m} \times 3.5 \mathrm{~m}$ (Figure 9), with rare clasts of amphibolite, banded iron formation, calcsilicate rocks and chert (Figure 10) set in a medium- to dark-grey sandy to gritty matrix. The clasts found in the 


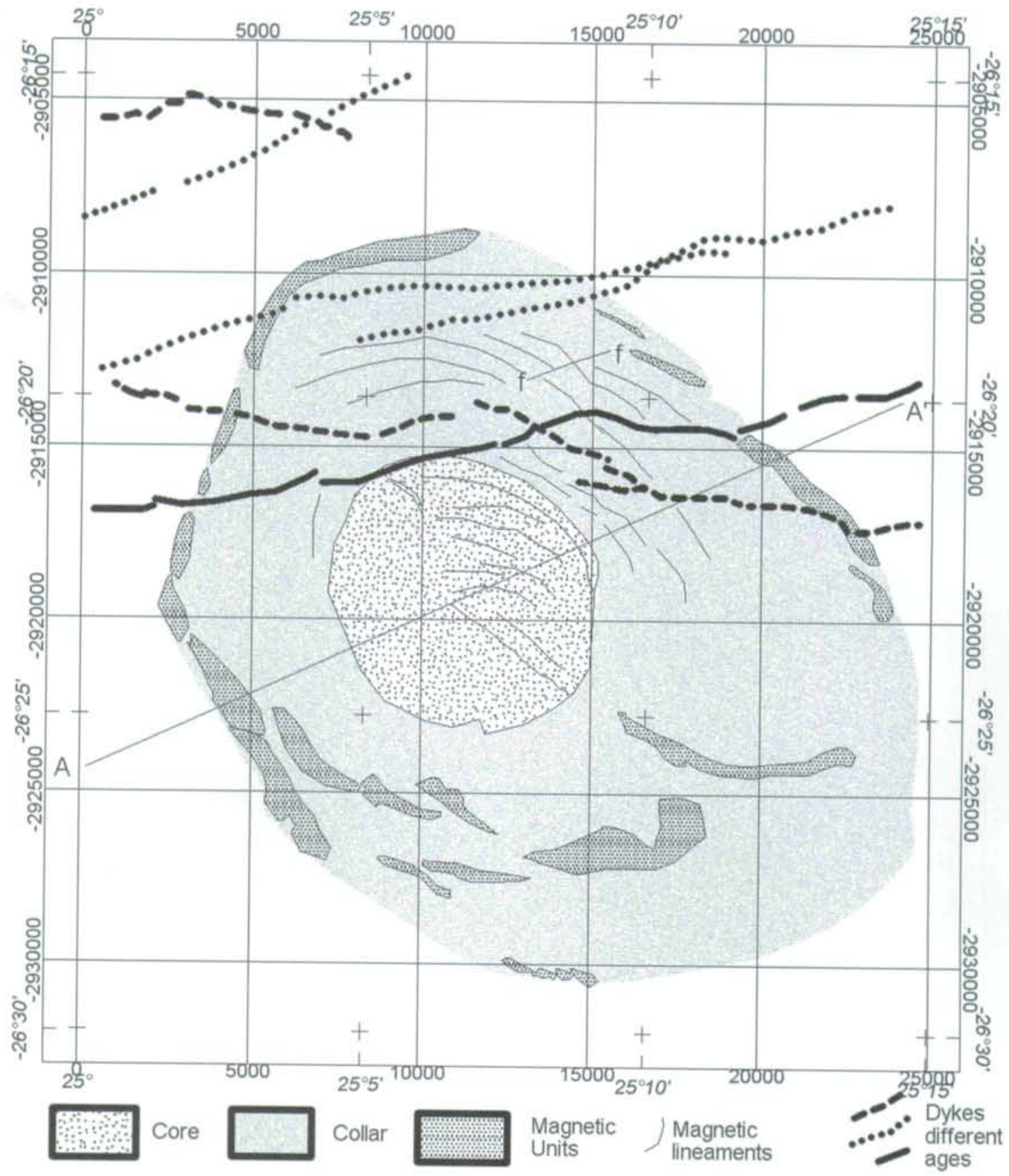

Figure 5. Simplified map of the Setlagole structure providing a simple interpretation of the magnetic patterns and lineaments observed in Figures 2 and 4. At least three ages of dykes cross-cut the structure, which is older than all the dykes. The dykes can be distinguished from one another on the basis of their aeromagnetic properties and pbysical relationships (see text).

northern exposure (Locality 2, Figures 1,8) are generally slightly smaller, but some large blocks, like that shown in Figure $9 \mathrm{~d}(3.2 \mathrm{~m} \times 1.5 \mathrm{~m})$, are also present. The breccia ranges from clast- to matrix-supported (Figures 8, 11, 12), Large-scale stratification based on fragment sorting and grading is noted locally but is not very apparent (Figure 12) and, in places, the matrix variations appear to be lateral rather than vertical. Centimetre- to millimetre-scale grain size variations are seen in the matrix between blocks, and define fluidal structures. Locally, the matrix grain size appears to decrease to silt-size particles and the matrix assumes a darker grey colour (Figure 13a, d). However, the northern exposure additionally displays at least one clast-poor, sandy unit up to $30 \mathrm{~cm}$ thick that defines a crude, gently northeast-dipping layering. Internal stratification and even crude cross-stratification (Figures $12 \mathrm{a}$ and $\mathrm{c}$ ) are present. 
A minor component of the clast population comprises irregular, commonly highly flattened black to dark-grey fragments, that appear to be molded between the lithic clasts (Figures 13a, d and 14c). The laminations may be highly distorted into fold-like patterns. These clasts are more common at Locality 1 , which is also where patches of dark matrix (Figure 13a and d) are more prevalent. Microscopic analysis indicates that both the clasts and the dark matrix are particularly rich in chlorite and that the clasts also occur on the micro-scale where they show similar irregular shapes. The clasts may, in turn, contain angular quartz and feldspar clasts that are considerably finer-grained than the equivalent mineral clasts in the adjacent matrix.

The irregular shapes of the dark clasts (Figures 13d and 14c) suggests that they were not lithified at the time of breccia formation. Two options are available - they represent sedimentary mud fragments ripped up during breccia formation, or they could represent molten fragments that were deformed prior to quenching. However, a further complication is found. Figure $14 \mathrm{c}$ shows an example of a black mass lying alongside a granite clast, but with extensions intruding into the granite clast. These 'intrusions' exploit fracture zones in the clast that contain veinlets ranging from $<1 \mathrm{~mm}$ to $5 \mathrm{~mm}$ in width that themselves contain clasts derived from the adjacent granite. This setting resembles that of pseudotachylite. Unfortunately, microscopic analysis indicates that the intraclast 'pseudotachylite' is completely recrystallized to chlorite and is largely indistinguishable from the dark fragments within the breccia. If this was originally pseudotachylite, then its presence is unique in the region. Such an interpretation raises questions about the origin of not only the dark fragment in Figure 14c, but of all the dark clasts. It is unlikely that conventional pseudotachylitic friction melt would have remained molten long enough to be separated from its host, broken up and still deformed ductilely as the breccia was deposited.

Relative to the bulk of the outcrop, the areas characterized by darker, finer-grained matrix in general show a more highly angular clast population (Figures 13a and d), Not all the irregular fluidal fragments are dark Figure 13d shows lighter-coloured clasts.

With the exception of the fluidal clasts, the lithic components of the breccia consist entirely of a variety of granitic, TTG and Kraaipan Group greenstone lithologies which occur in the region (SACS, 1980; Zimmerman, 1994; Hirner, 2001; Brandl et al., 2006).

\section{Microscopic observations}

Microscopic examination of the megabreccia matrix reveals that it is dominated by angular mineral fragments of monocrystalline quartz, plagioclase and alkali feldspar (microcline, locally perthitic), with subsidiary polycrystalline and rarer polymineralic fragments derived from the granitoid basement lithologies (Figure 15). Grain size is highly variable, ranging from $\sim 0.2$ to $1 \mathrm{~mm}$, but shows some consistency within individual thin sections. Limited saussuritisation of the plagioclase is present, but microcline is usually less altered. Epidote occurs in most samples and sphene is found more rarely. Highly chloritized fragments up to 2 to $3 \mathrm{~mm}$ long suggest replacement of biotite and/or

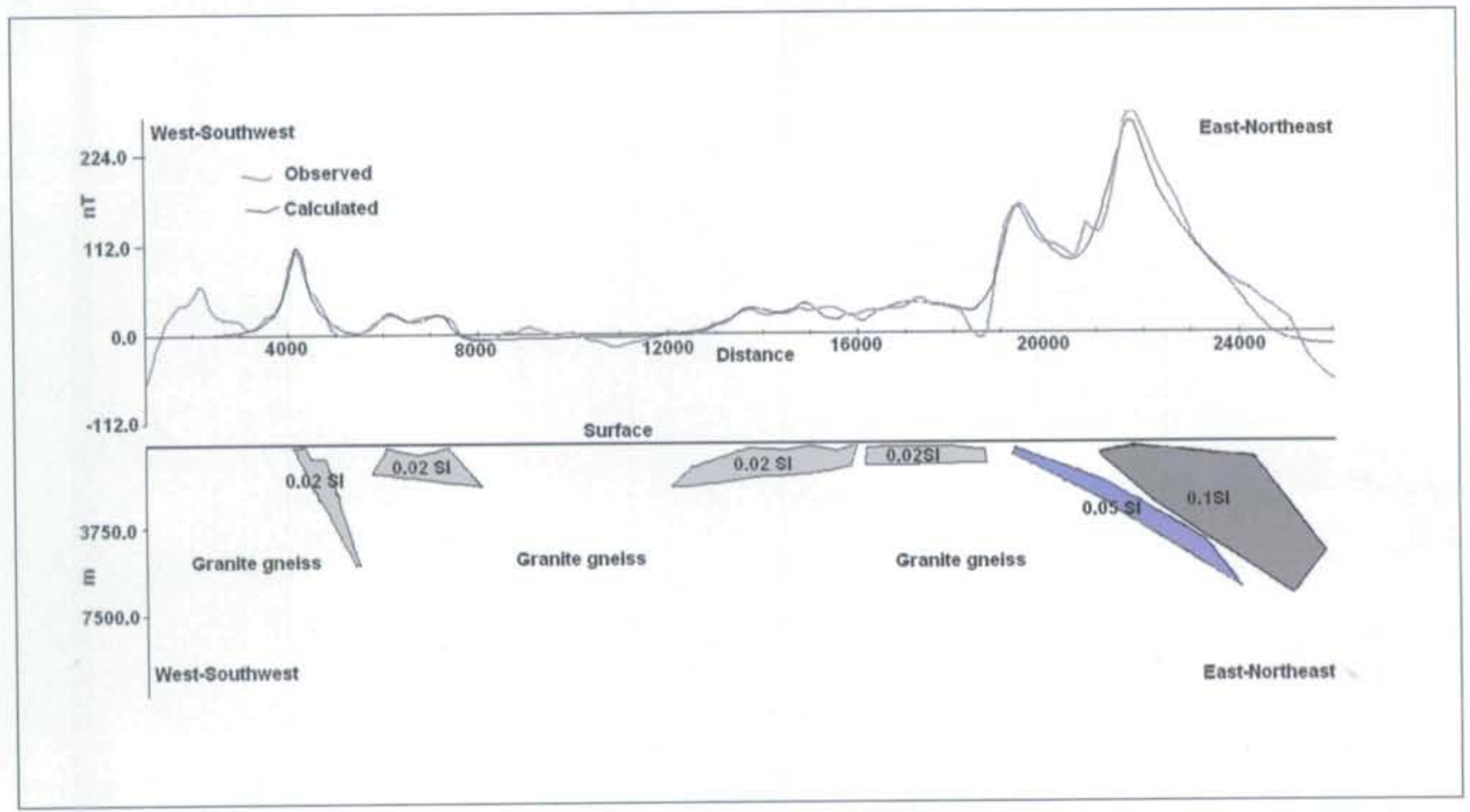

Figure 6. Profile of magnetic values extracted along a east-northeast to west-soutbuest trending traverse across the Setlagole anomaly (see text). 
amphibole aggregates. Together with the epidote and sphene, these fragments suggest a subsidiary amphibolite source, Muscovite is present locally, and zircon is common.

The interstices between the quartzofeldspathic fragments comprise mainly chlorite. However, abundant evidence of biotite relics within the chlorite masses indicates that this is a replacement texture, with the $\mathrm{Ti}$ component in the biotite being taken up in small rutile clusters in the chlorite. This indicates that the breccia has been metamorphosed to lower greenschist facies. The biotite clasts show undulose extinction that is locally related to deformation around other mineral clasts. Evidence of corrosion of clasts (e.g., Figure 15b, $c$ and e) and the penetration of chlorite masses into fractures within quartz and even along plagioclase twins (Figures 15c, e, f and g) indicates the involvement of significant amounts of fluid in this metamorphism. Nonetheless, the clasts retain evidence of myloniterelated undulose and mosaic extinction, deformation bands and subgrain development in quartz, and fractures and kinks in feldspar. Lobate myrmekitic quartz-plagioclase intergrowths (Figure 15i) appear to be unusually common relative to the rest of the region. It is unclear if they are the product of granite crystallization or subsolidus deformation and/or metasomatic fluid movement, possibly associated with the mylonitic deformation observed locally in the clasts (Collins, 1997). At least some of the feldspar alteration is linked to this mylonite event.

Irregular opaque grey masses within the breccia (Figure 15d) display a cryptocrystalline matrix of mainly chlorite in which are set angular quartz, feldspar and biotite clasts that are typically, but not always, $<0.1 \mathrm{~mm}$ in size. These masses have highly irregular edges that interfinger with the coarser breccia matrix. Biotite fragments within them may display crude alignment. These masses are correlated with the dark clasts seen in outcrop and suggest that the latter are also present at the micro-scale.

Despite examination of more than 60 thin sections, no conclusive evidence of shock metamorphism in the
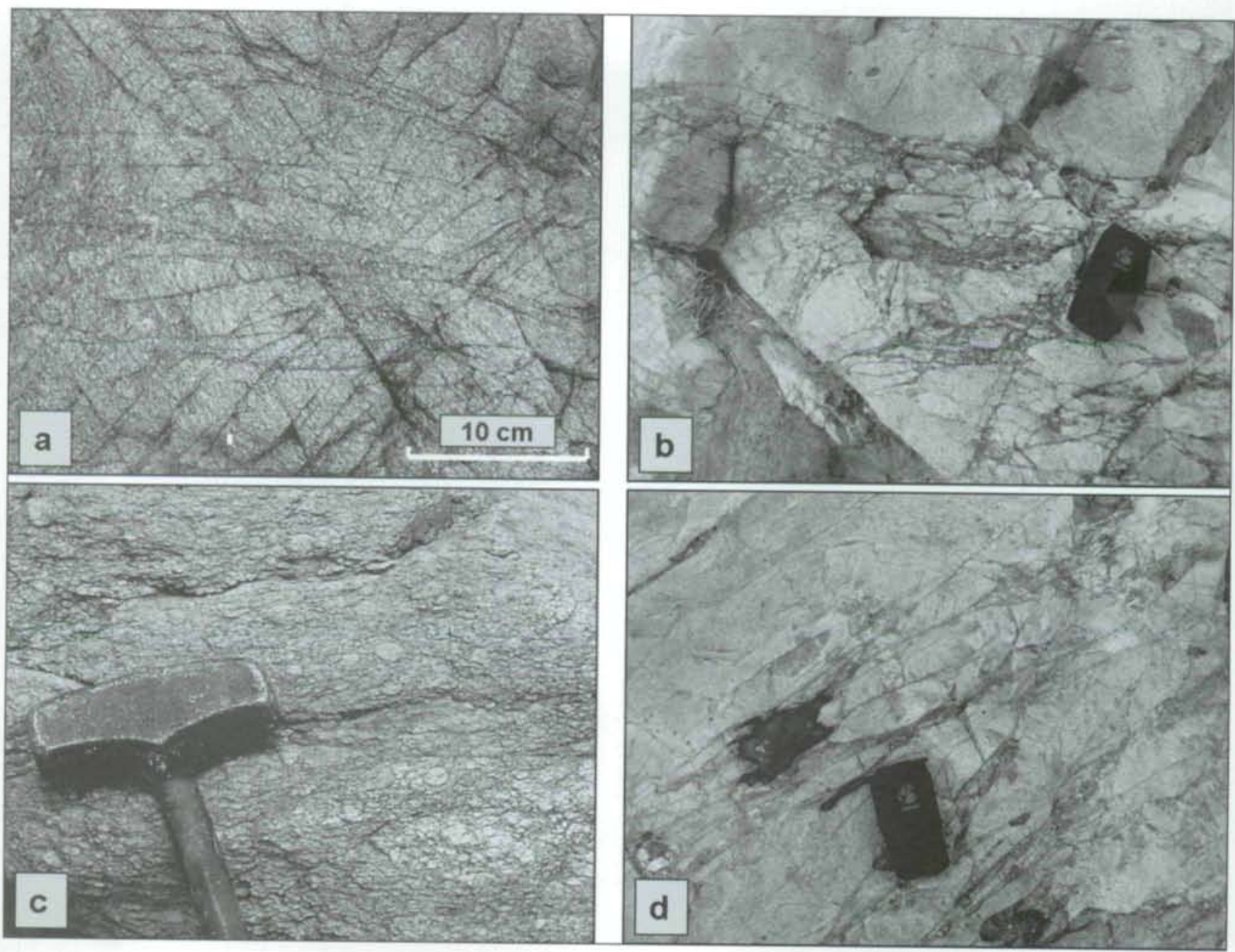

Figure 7. Deformation features in the granitic terrane betueen Setlagole and Madibogo. (a) Photograph sbowing closely-spaced intersecting fracfure sets in granitic gneiss. (b) Fault breccia in granitoid gneiss in the stream soutb of Setlagole. (c) Feldspar porpbyroclasts and mylonitic (?) fabric in coarse-grained or porpbyritic granite. (d) Mylonitic shears and fractures, and local brecciation, in fine-grained granite. The sbear planes contain a filling of quartz-chlorite-epidote. 


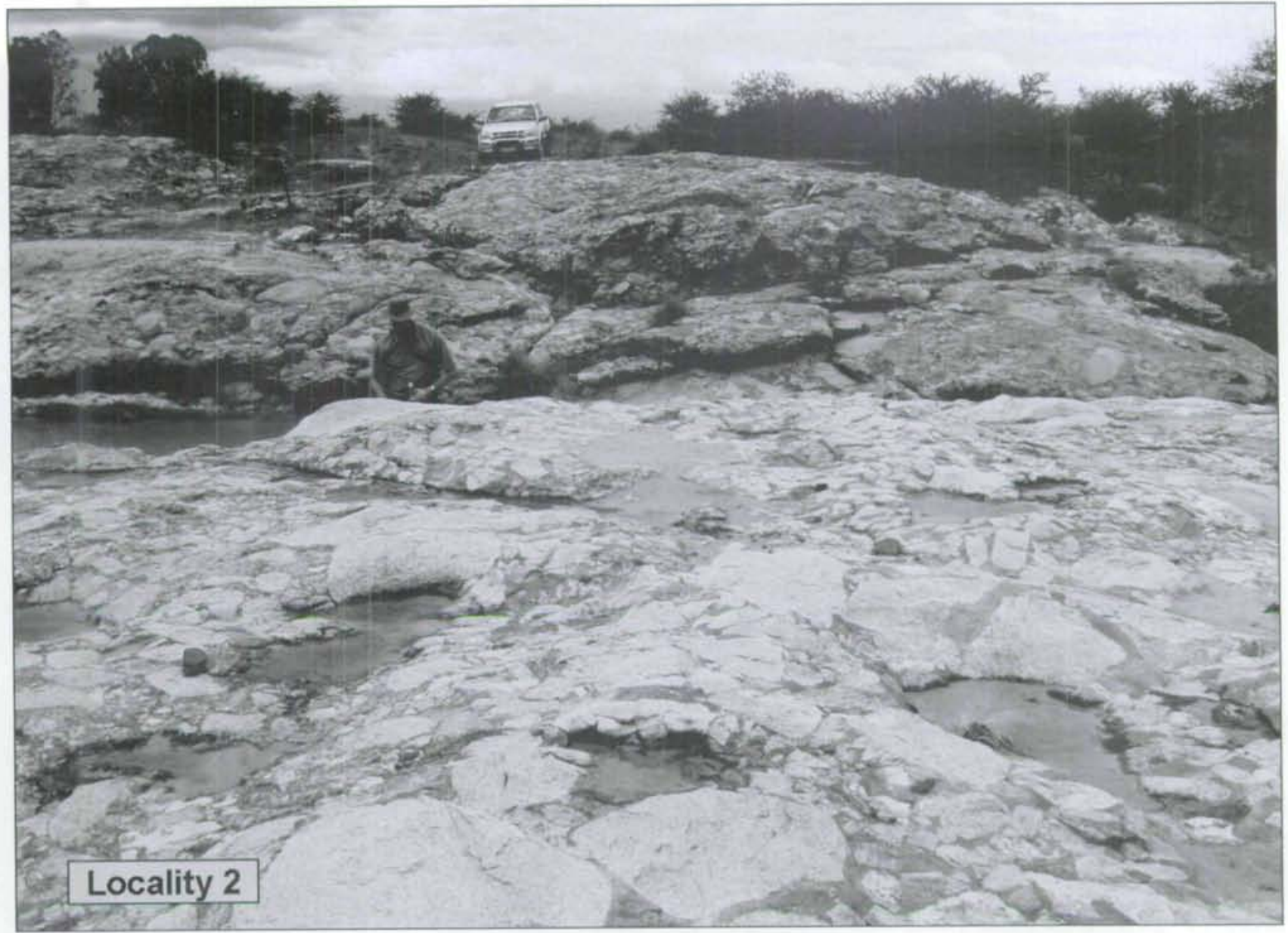

Figure 8. General view of the Setlagole megabreccia exposed in the streambed at Locality 2. The breccia is at least $5 \mathrm{~m}$ thick and displays layering dipping gently to the nortbeast (left).

form of planar deformation features (PDFs) has been recognized although rare grains with multiple sets of planar fluid inclusion trails have been found (Figure 15h). In some cases, unusually fine-grained cherty recrystallization of the margins of quartz grains, and similar recrystallization in feldspar, is evident. Although the irregular nature of these features does not fit the pattern normally associated with dynamic recrystallization and, thus, may be suggestive of recrystallized diaplectic glass, they are far less common than the dynamic recrystallization features and could, perhaps, reflect thin sectioning effects. No PDFs were found in any of the zircon crystals examined. Special attention was paid to clasts contained within the dark fine-grained clasts, but these show no unusual features relative to the quartz and feldspar clasts in the rest of the breccia.

The greenschist facies metamorphic overprint may, potentially, have been responsible for the recrystallization and annealing of whatever PDFs may have survived an impact event. Although the grade of metamorphism is lower than most parts of the Vredefort Dome in which decorated PDFs still survive (e.g., Grieve et al., 1990), the microtextural evidence from the Setlagole breccia indicates the involvement of far more fluid than appears to have been the case following the Vredefort impact event, which may have facilitated recrystallization.

\section{Megabreccia geochemistry \\ Megabreccia clasts and Kraaipan granite- greenstone basement}

A variety of clasts from the megabreccia exposures were analysed to establish their composition and for comparison with rocks of the Kraaipan granitegreenstone basement terrane. Major and trace element compositions of the megabreccia were determined by XRF analysis at the School of Geosciences, University of the Witwatersrand. The predominantly granitic rocks are grouped into pinkish-grey granodiorite, leuco-trondhjemitic gneiss, melanocratic tonalite/ trondhjemite, melanocratic diorite/tonalite and diorite/ gabbro (Table 1, columns 1 to 12). An amphibolite clast and Kraaipan banded iron formation are also listed (Table 1, columns 13 and 14), Geochemically the rocks of the megabreccia compare favourably with those of rock types found in the surrounding Kraaipan granitegreenstone terrane ( $c f$., Anhaeusser and Walraven, 1999; Hirner, 2001).

Harker diagrams of major elements (Figure 16) show that most elements display compatible behaviour, all 


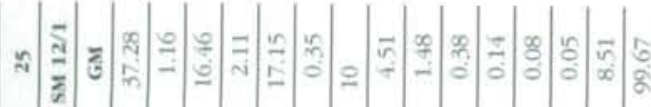

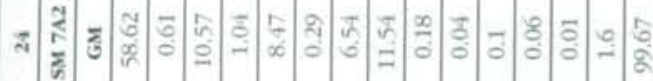

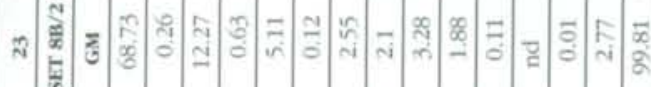

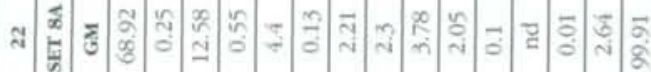

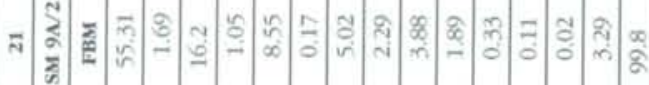

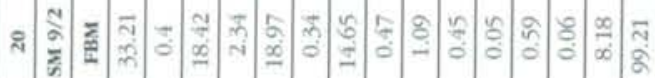

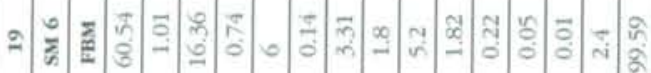

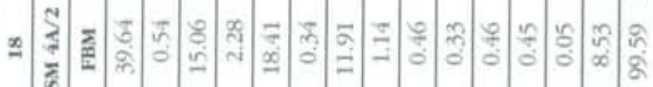

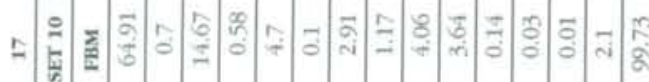
$=\sqrt{\frac{1}{4}}$

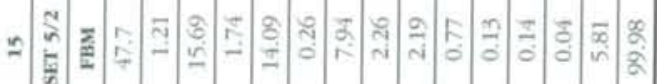

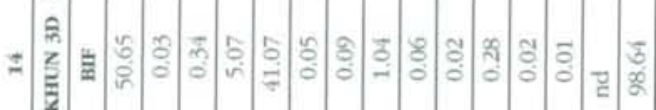

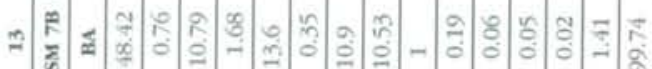

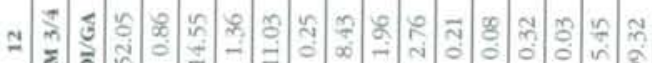

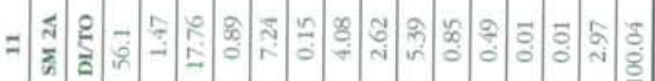

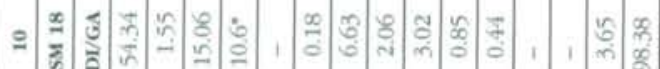
-

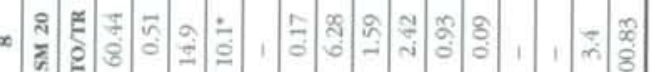

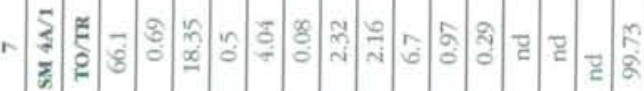

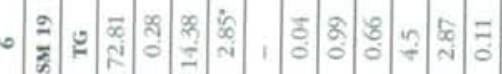
-

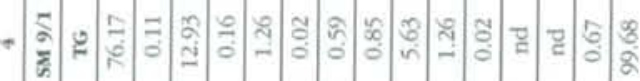

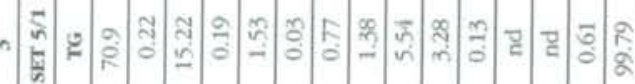

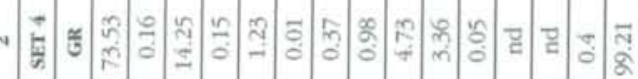

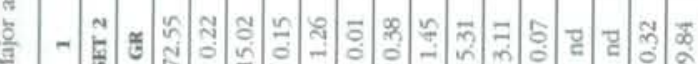

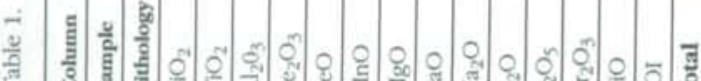

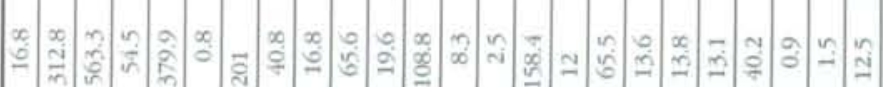

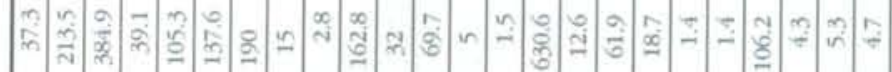

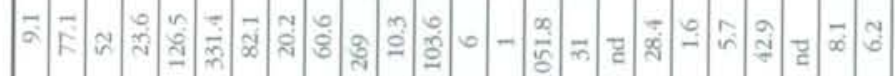

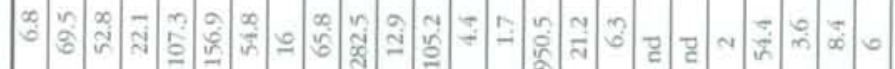

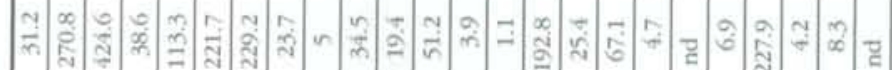

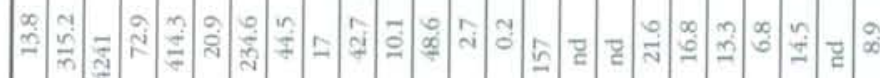

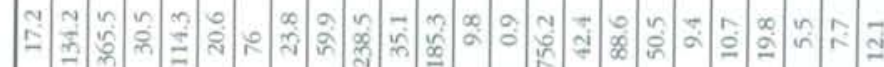

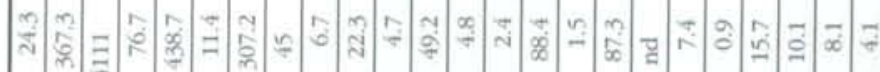

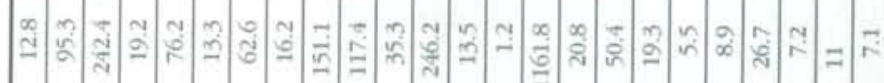

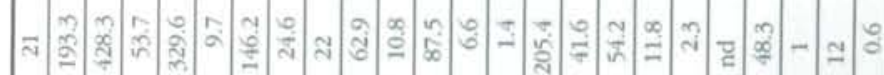

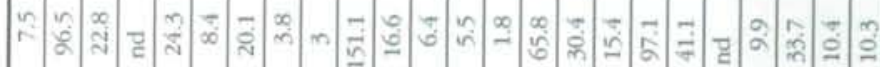

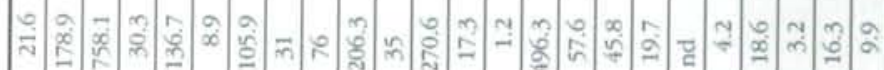

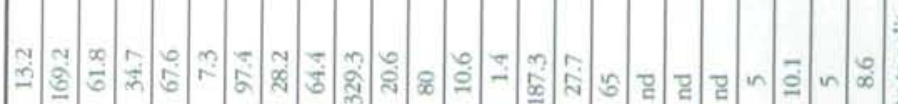

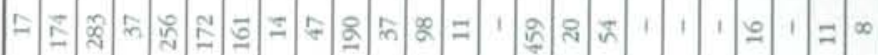
学望 然

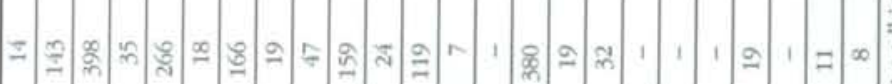
童

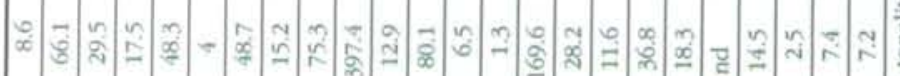

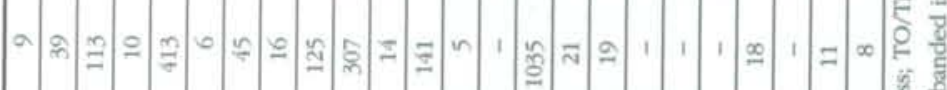

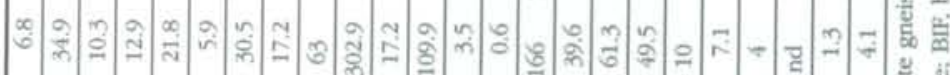

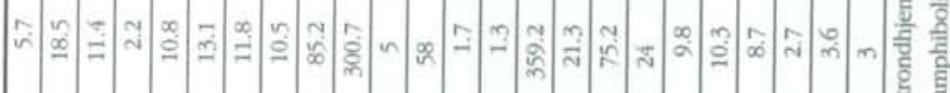

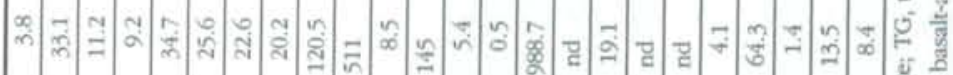

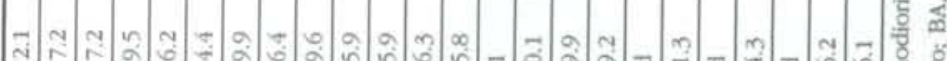

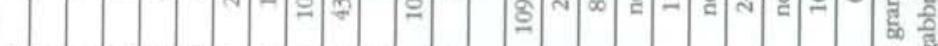

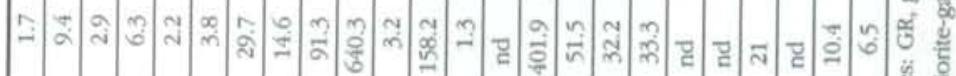
这 을 
Table 2. Setlagole breccia matrix - REE content of dark chlorite-bearing clasts compared to average upper, middle and lower crustal values

\begin{tabular}{|c|c|c|c|c|c|c|}
\hline Column & 1 & 2 & 3 & 4 & 5 & 6 \\
\hline Sample & $\mathrm{SM} 4 \mathrm{~A} / 2$ & SM9/2 & $\operatorname{Sm12/1}$ & Upper Crust \#1 & Middle Crust \#2 & Lower Crust \#3 \\
\hline $\mathrm{La}$ & 4.91 & 6.84 & 5.61 & 30 & 17 & 8 \\
\hline $\mathrm{Ce}$ & 8.34 & 17.53 & 10.89 & 64 & 45 & 20 \\
\hline $\operatorname{Pr}$ & 1.07 & 1.99 & 1.71 & 7.1 & 5.8 & 2.6 \\
\hline $\mathrm{Nd}$ & 4.05 & 8 & 7.86 & 26 & 24 & 11 \\
\hline Sm & 0.83 & 2.04 & 2.14 & 4.5 & 4.4 & 2.8 \\
\hline $\mathrm{Eu}$ & 0.22 & 0.65 & 0.61 & 0.88 & 1.5 & 1.1 \\
\hline Gd & 0.87 & 1.93 & 2.06 & 3.8 & 4 & 3.1 \\
\hline $\mathrm{Tb}$ & 0.12 & 0.25 & 0.3 & 0.64 & 0.58 & 0.48 \\
\hline Dy & 0.66 & 1.39 & 1.64 & 3.5 & 3.8 & 3.1 \\
\hline Ho & 0.13 & 0.29 & 0.31 & 0.8 & 0.82 & 0.68 \\
\hline Er & 0.4 & 0.84 & 0.84 & 2.3 & 2.3 & 1.9 \\
\hline $\mathrm{Tm}$ & 0.06 & 0.13 & 0.13 & 0.33 & - & - \\
\hline $\mathrm{Yb}$ & 0.41 & 0.83 & 0.81 & 2.2 & 2.3 & 1.5 \\
\hline $\mathrm{Lu}$ & 0.06 & 0.13 & 0.12 & 0.32 & 4.1 & 0.25 \\
\hline \multicolumn{7}{|l|}{ Norms } \\
\hline Quartz & 2.38 & & & & & \\
\hline Corundum & 12.97 & 11.42 & 5.75 & & & \\
\hline Orthoclase & 1.95 & 2.66 & 2.25 & & & \\
\hline Albite & 3.89 & 9.22 & 12.52 & & & \\
\hline Anorthite & 2.65 & 1.96 & 21.46 & & & \\
\hline Hypersthene & 61.33 & 22.23 & 15.35 & & & \\
\hline Olivine & & 34.63 & 28.11 & & & \\
\hline Magnetite & 3.31 & 3.39 & 3.06 & & & \\
\hline Ilmenite & 1.03 & 0.76 & 2.2 & & & \\
\hline Apatite & 1.07 & 0.12 & 0.3 & & & \\
\hline
\end{tabular}

*1 - Upper crust data from Taylor and Mclennan $(1985,1995)$

$\neq 2-* 3-$ Middle and Lower crust data from Rudnick and Fountain (1995)

Continental crust data $\approx 1-\approx 3$ provided in tables in White (2001).

samples plotting along similar trends. However, $\mathrm{TiO}_{2}$, $\mathrm{P}_{2} \mathrm{O}_{5}, \mathrm{~K}_{2} \mathrm{O}$ and $\mathrm{Na}_{2} \mathrm{O}$ show some scatter possibly reflecting mobility of these elements as a result of alteration/metamorphism. Average $\mathrm{CI}$ chondrite values, plotted on the diagrams, (after Anders and Grevesse, 1989) show only partial compatibility with the Setlagole sample sets.

Trace element Harker diagrams (Figure 17) show, for the most part, similarly compatible plots, with two samples (SM9/2 and SM 4A/2) displaying anomalously high $\mathrm{Cr}$ values in excess of $4000 \mathrm{ppm}\left(\mathrm{SiO}_{2}\right.$ vs $\mathrm{Cr}$ plot).

\section{Megabreccia matrix clasts}

Selected sampling of megabreccia matrix clasts (specifically the irregular-shaped, fine-grained, dark-grey to black clasts, like those shown in Figures 13 and 14, as well as the gritty or sandy sediment shown in Figure 12) was undertaken as it was thought that this material might help determine whether they represent possible metamorphosed impact melt clasts or fine-grained sedimentary impact debris.

The major and trace element compositions of the megabreccia matrix material are listed in Table 1 (columns 15 to 25 ). Every attempt was made to analyse only clasts with minimal inclusions, but some contamination was unavoidable as the matrix material is never entirely free of microscopic particles. Many of the major element analyses reveal that the matrix material has a generally similar composition to the prevailing TTG basement lithologies, ranging from diorites to tonalites (Table 1). The absence of a granitic bulk composition for some of the dark-grey matrix samples is consistent with their high chlorite content as seen in thin sections

Trace element analyses of some of the dark-grey matrix clasts (e.g., samples SET8B/1, SM4A/2, SM9/2, $\mathrm{SM} 9 \mathrm{~A} / 2$, and $\mathrm{SM} 12 / 1$ ) revealed anomalous $\mathrm{Ni}, \mathrm{Cr}, \mathrm{V}, \mathrm{Zn}$ and $\mathrm{Co}$ values relative to available data from Kraaipan granitoid rocks and the Setlagole megabreccia clasts (Table 1 and Figure 17). For example, Hirner (2001) listed trace element data from granitoid rocks in the Madibe area, approximately $50 \mathrm{~km}$ northeast of Setlagole, where the average values of $\mathrm{Ni}$ and $\mathrm{Cr}$ analyses from tonalite-trondhjemite-granodiorite samples yielded $62 \mathrm{ppm} \mathrm{Ni}$ and $124 \mathrm{ppm}$ $\mathrm{Cr}$ - both amounts being substantially lower than the values obtained from the matrix clasts of the Setlagole breccia (cf., Table 1). 

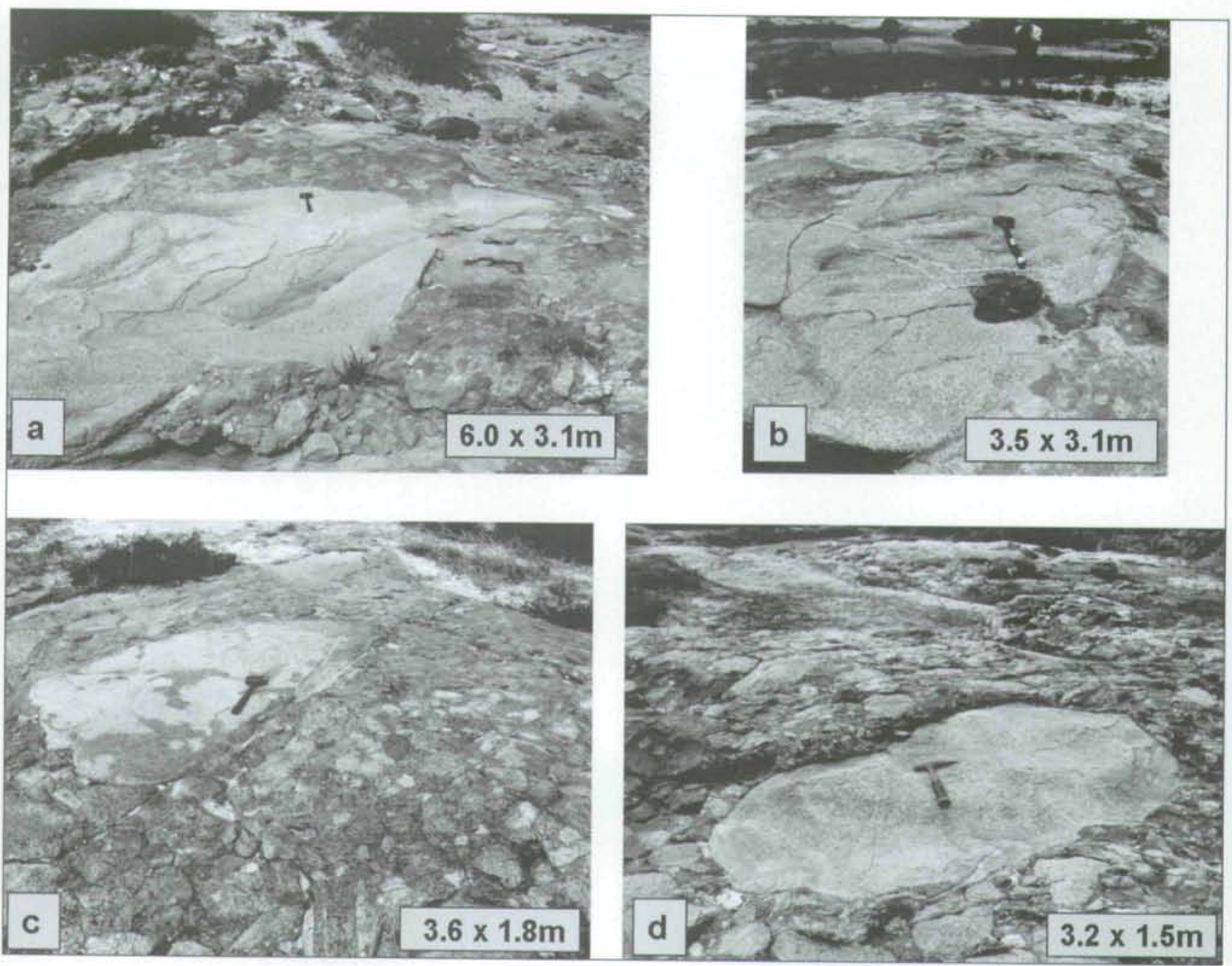

Figure 9. Setlagole megabreccia blocks tllustrating the bigbly variable clast size. (a) Largest granitic block, measuring 6 m $x$. 3.1 . enteloped in dark matrix breccia. Locality 1. (b) Granitic block $3.5 \mathrm{~m} \times 3.1 \mathrm{~m}$ enclosed in breccia, Locality 1 . (c) Granitic block measuring $3.6 \mathrm{~m} \times 1.8 \mathrm{~m}$ surrounded by smaller breccia fragments encased in matrix breccia, Locality 1. (d) Largest granitic block (3.2 $m$. $1.5 \mathrm{~m}$ ) in breccia at Locality 2. The largest megabreccia blocks occur at Locality 1. The size cbanges may reflect otverall upward-fining of the breccia tousards Locality 2 .

\section{REE content of matrix clasts}

In view of the anomalously high trace element amounts of $\mathrm{V}, \mathrm{Cr}, \mathrm{Ni}$, and $\mathrm{Zn}$ noted above, samples $\mathrm{SM} 4 \mathrm{~A} / 2$. Sm $9 / 2$ and SM12/1 were selected for REE analysis. The results, listed in Table 2 and plotted in Figure 18, are compared with average REE data from upper, middle and lower continental crust (Taylor and McLennan, 1985; 1995; Rudnick and Fountain, 1995). The plots reveal patterns of LREE enrichment and moderate to strong HREE depletion for both the Setlagole data and the continental crust. The Setlagole data also shows lower overall abundances relative to the continental crust, the closest similarity being with the lower continental crustal signature. Sample SM $4 \mathrm{~A} / 2$ and the upper crust both display negative europium anomalies.

The unusual nature of the Setlagole matrix samples is also evident from norm calculations (Table 2), with silica and feldspar undersaturation $(\mathrm{Q}, \mathrm{Ab}, \mathrm{An}, \mathrm{Or})$ and normative corundum, hypersthene and olivine $(\mathrm{Co}, \mathrm{Hy}$, Ol) predominant. The circumstances which led to this unusual normative mineralogy may have involved deuteric alteration, metamorphism, and fluid migration within the breccias, the latter causing dissolution and leaching of some of the constituents. The composition of the primary host material (target rocks?) remains conjectural at this stage, but the scenario favoured here, is that the dark clasts in the megabreccia matrix originally represented impact melt material (glass) which altered to chlorite. Such alteration, according to Sivell and Rankin (1983), would cause loss of Ca and a marked decrease in normative diopside relative to higher amounts of normative hypersthene and olivine (cf., Table 2).

The available major, trace and REE data do not provide unequivocal geochemical support for possible meteoritic involvement with respect to the Setlagole megabreccia and the breccia matrix material. However, they do show that the matrix clast material is geochemically unusual and that it cannot readily be correlated with any other rocks in the region. 

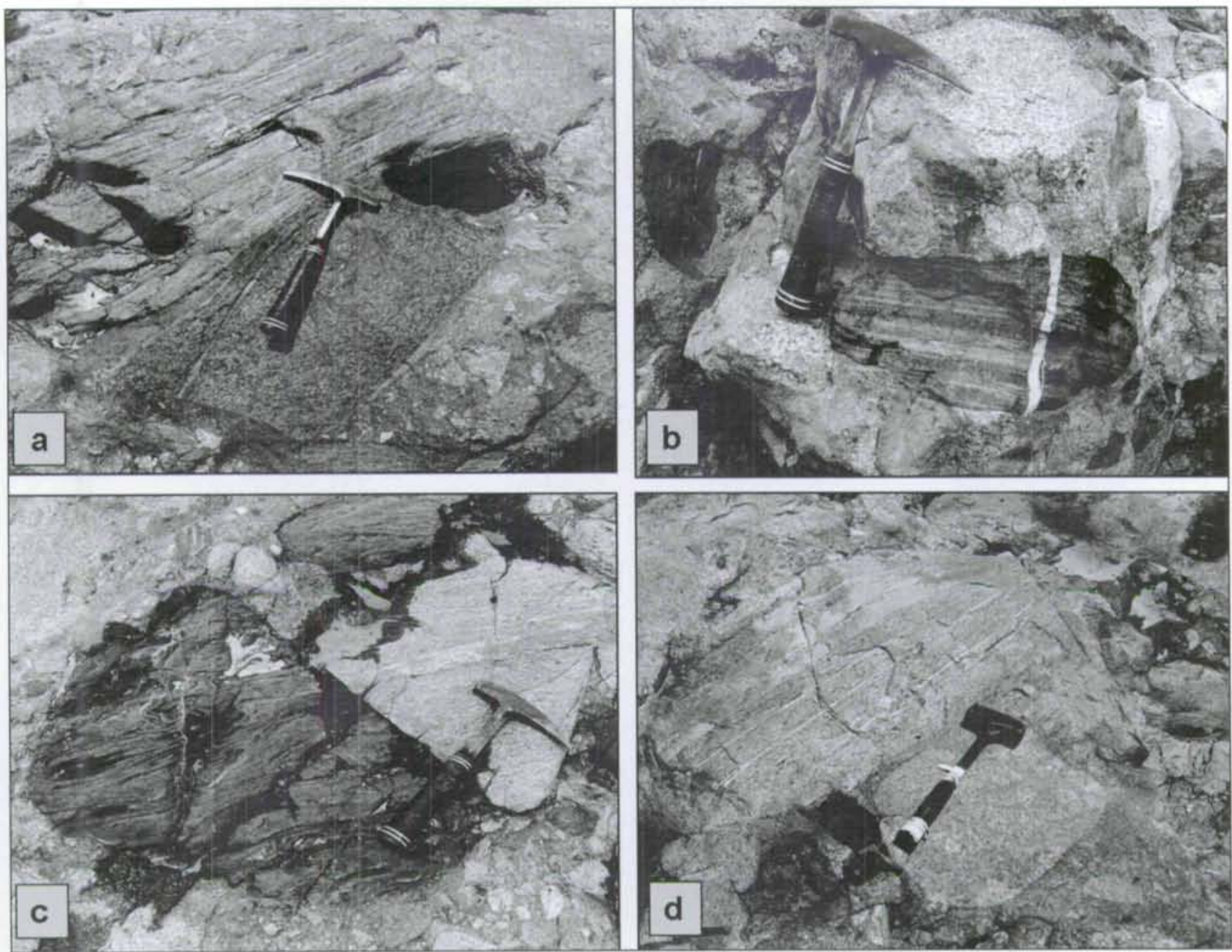

Figure 10. Setlagole megabreccia showing main clast litbologies. (a) Fragments of recrystallized Kraaipan Formation chert (top left) and tonalite (beneath hammer). (b) Rounded fragment of Kraaipan Formation banded calc-silicate rock cut by a pre-impact quartz vein, and an ampbibolite clast (left of hammer). (c) Kraaipan Formation ampbibolite clast displaying folds and occurring juxtaposed against a clast of banded gneiss. (d) Banded trondbjemitic gneiss fragment next to a bomogeneous granitic block (beneatb bammer). Smaller dark fragments of ampbibolite occur left of the bandle base.

In similar vein, studies of what has been described as a highly unusual rock type associated with the Vredefort impact structure (viz., the Vredefort Granophyre), found it had a 'puzzling' composition (being approximately that of a granodiorite), but characterized by a high $\mathrm{Mg} / \mathrm{Fe}$ ratio, low $\mathrm{Al}$ and $\mathrm{Na}$ concentrations (French and Nielsen, 1990), and high $\mathrm{Si}$ and $\mathrm{Ca}$ (Gibson and Reimold, 2008), Reimold and Gibson (2005) further claimed that the Granophyre does not have a counterpart in geological and geochemical textbooks. French and Nielsen (1990), Therriault et al. (1997b) and Reimold et al. (1990) employed computer modeling techniques, and believed that the unusual composition of the Granophyre was produced by impact melting and mixing of pre-Vredefort target rocks (basement granitegneiss, Witwatersrand shale and quartzite, Ventersdorp lava, and Transvaal carbonate rock). These authors dismissed assimilation of the wall rocks as improbable unless it could be demonstrated that unreasonable amounts of wall rock were assimilated.
Thus, it can be argued that the absence, to date, of any direct link of the Setlagole matrix material with a meteoritic origin does not negate this possibility. Further geochemical study, which is beyond the scope of this investigation, advocates the analysis of siderophile element concentrations (iridium enrichment and Re-Os isotopic tracer methods) as possible means of detecting any potential meteoritic component for the Setlagole breccia matrix.

\section{Discussion}

\section{Age relationships}

No direct age dating of the Setlagole breccia or the circular structure has yet been attempted. However, indirect lines of evidence, discussed here, suggest the structure may be of Mesoarchaean age. As indicated earlier, the breccia comprises rock fragments derived solely from the Archaean Kraaipan granite-greenstone basement, which it overlies. Although Ventersdorp (ca. $2.71 \mathrm{Ga}$ ) and Transvaal (ca. 2.64 to $2.22 \mathrm{Ga}$ ) Super- 
group rocks occur in the region (Armstrong et al., 1991; Keyser, 1998; Eriksson et al., 2006), no fragments of these rocks have been found in the breccia, suggesting that these formations had not yet been deposited when the breccia formed.

Second, the breccia experienced a low-grade metamorphic event that does not appear to be recorded in the Ventersdorp and Transvaal successions. Miyano and Beukes (1984) and N. J. Beukes (personal communication, 2009) reported that metamorphism in the Transvaal rocks of the Northern Cape and North West Province is of a very low grade (upper diagenetic facies, in the order of 110 to $200{ }^{\circ} \mathrm{C}$ ). The grade increases locally to greenschist facies only adjacent to diabase sills and dykes. Keyser (1998) likewise reported only low-grade alteration, including uralitization, epidotization, saussuritization and chloritization of the Ventersdorp rocks in the region, which he ascribed mainly to localized hydrothermal processes. Cornell (1978) supported burial metamorphism and metasomatism to explain the alteration seen in the Ventersdorp volcanic rocks.

The greenschist facies metamorphism in the breccia is also not as high-grade as the upper amphibolite facies metamorphism encountered in the Kraaipan greenstone fragments. Metamorphism in the Kraaipan greenstone belt accompanied granitoid rock emplacement between ca. 3.19 Ga and $2.79 \mathrm{Ga}$ (Anhaeusser and Walraven, 1999; Poujol et al., 2002; 2003; Schmitz et al., 2004), thus placing an upper age limit on the breccia.

Third, geophysical evidence suggests that the Setlagole structure predates at least three dyke events, which show up clearly on the aeromagnetic images (Figures 2 to 4). The youngest set of dykes in the North West Province is probably associated with Karoo magmatism (ca. $183 \mathrm{Ma}$, Duncan and Marsh, 2006), and appears to have been disrupted by the $145 \mathrm{Ma}$ old Morokweng impact structure located $135 \mathrm{~km}$ to the west of Setlagole (Corner et al., 1997; Hart et al., 1997; Andreoli et al., 2008 a; b). However, according to Corner
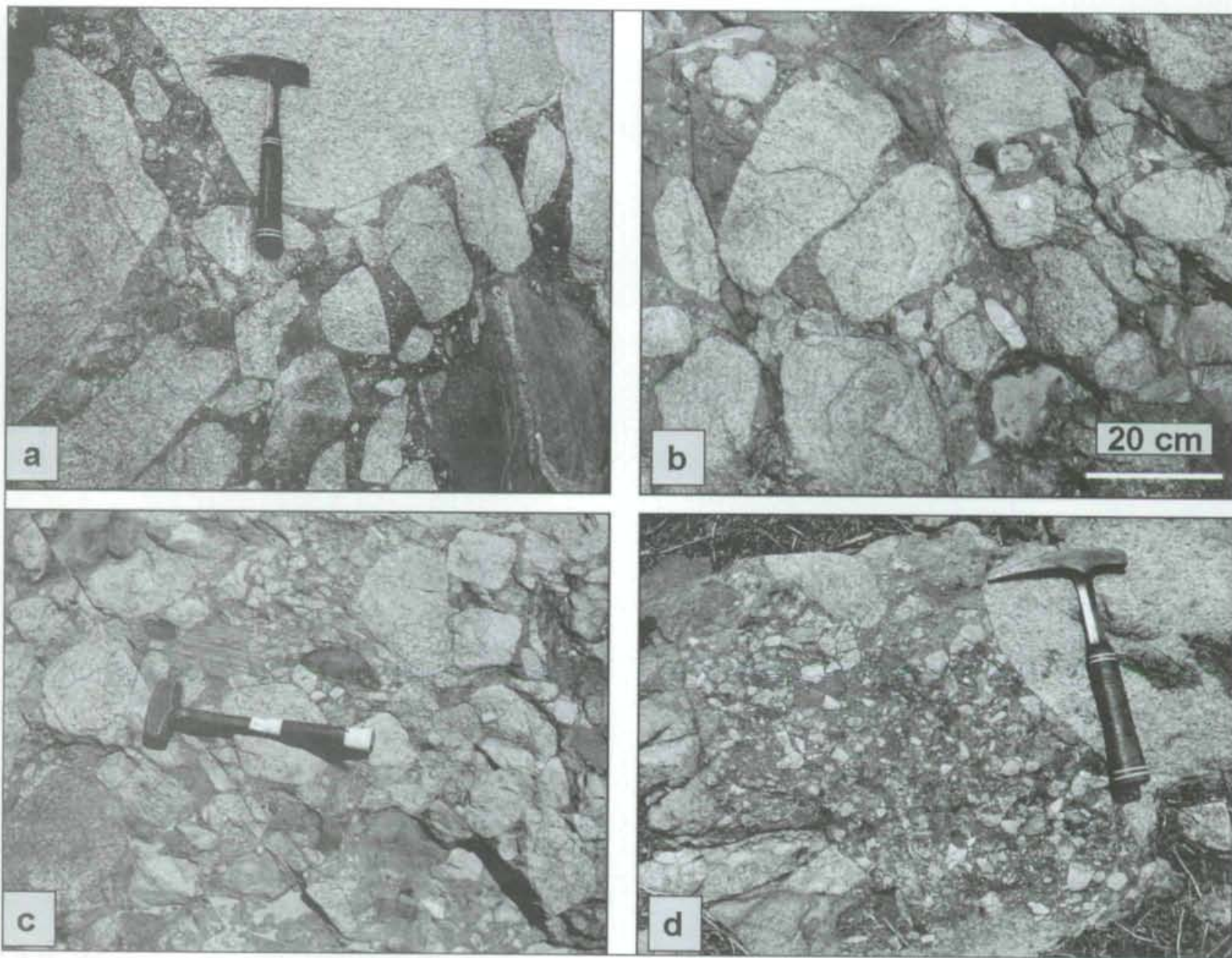

Figure 11. Setlagole megabreccia matrix tarieties. (a) Angular granitic and gneissic fragments (up to a metre in size) in a dark matrix containing smaller angular rock fragments. (b) Rounded-to-subangular granitiod rock fragments in a dark, fine-grained matrix breccia containing fewer centimetre-sized clasts. (c) Densely packed rock fragments showing a wide range of clast sizes and shapes, with comparatively little matrix. (d) Dark matrix breccia packed with small angular rock fragments occurring as infill breccia betueen larger granitoid fragments. 
et al. (1997), there may be an even younger (fourth) dyke event in the North West Province, represented by an east to west trending dyke (Machavie dyke), which cuts through the centre of the Morokweng structure, and is possibly of Cretaceous age (ca. 142 to $65 \mathrm{Ma}$ ).

Some of the dykes in the Setlagole area may represent feeders to the Ventersdorp volcanic succession. Examination of 1: 1000 000-scale aeromagnetic maps of South Africa (Council for Geoscience, 1997; Reed, 1996) further reveals a set of east-northeast trending mafic dykes cutting the Kraaipan basement terrane, including the Setlagole structure. These dykes terminate in the west against formations of the Olifantshoek Supergroup (Figure 3a, the latter having been dated at ca. 1.93 to $1.89 \mathrm{Ga}$ - Armstrong, 1987; Cornell et al., 1998; Moen, 2006). The same set of mafic dykes also appears to be truncated in the east (Figure 3b) by the Rustenburg layered Suite in the western limb of the Bushveld Complex, which is dated at ca. 2.06 to $2.05 \mathrm{Ga}$ (Walraven et al., 1990; Walraven and Hattingh, 1993). Interpretation of the aeromagnetic data for the southern part of the Setlagole structure in the context of the surface geology suggests that the structure is overlain by Ventersdorp Supergroup lavas west-southwest of Madibogo (Figures 2 and 4). If the age relationships reported above are correct, it would indicate that the Setlagole structure, like the megabreccia, is a Mesoarchaean feature.

\section{Origin of the Setlagole structure}

Evidence has been presented here of a multi-ring feature, possibly up to 25 to $30 \mathrm{~km}$ wide, that is indicated by the aeromagnetic data. Outcrop evidence of anomalous (i.e., for the Setlagole region) northeasterly to east-northeasterly trends for banded iron-formations along the northern margin of the feature supports some structural disturbance associated with the magnetic anomaly. However, the generally massive nature of the TTG rocks that underlie most of the anomaly, and their poor exposure, do not allow detailed structural analysis.
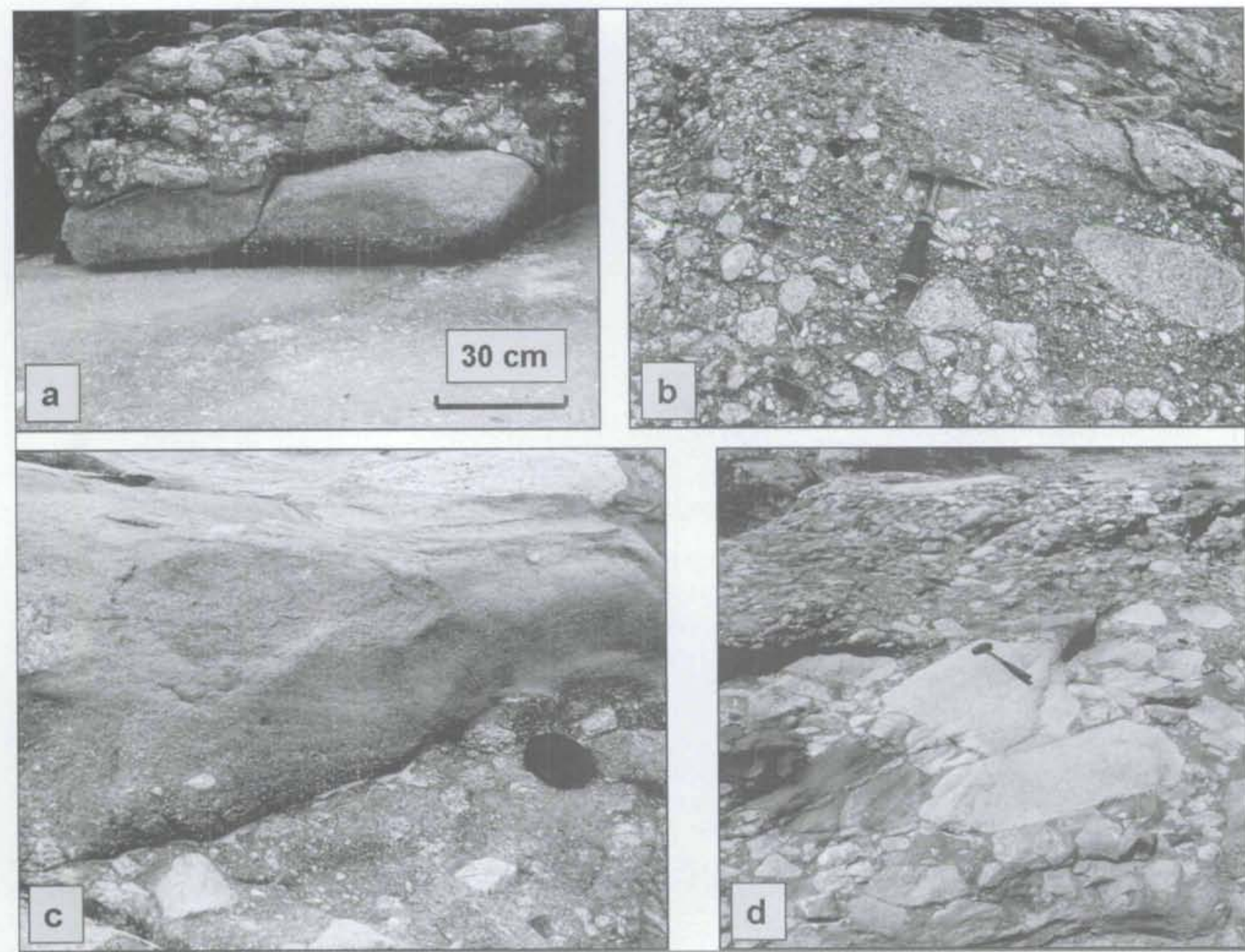

Figure 12. Sedimentary layering in megabreccia at Locality 2. (a) Sandy layer containing small breccia fragments and sbouing fine-scale layering, overlain by coarser breccia that appears to cut doumwards to the left. (b) Breccia fragments encased in dark matrix breccia showing a weak, upward-fining, gradational layering. (c) Matrix-supported breccia overlain by ueakly bedded sandy deposit. Note tbe isolated clasts and sometwat irregular bedding in the sandy layer, and tbe trregular basal contact of the sandy layer (d) Granite blocks encased in dark matrix breccia overlain by a layer comprising smaller clasts (abote bammer), suggesting large-scale grading. 

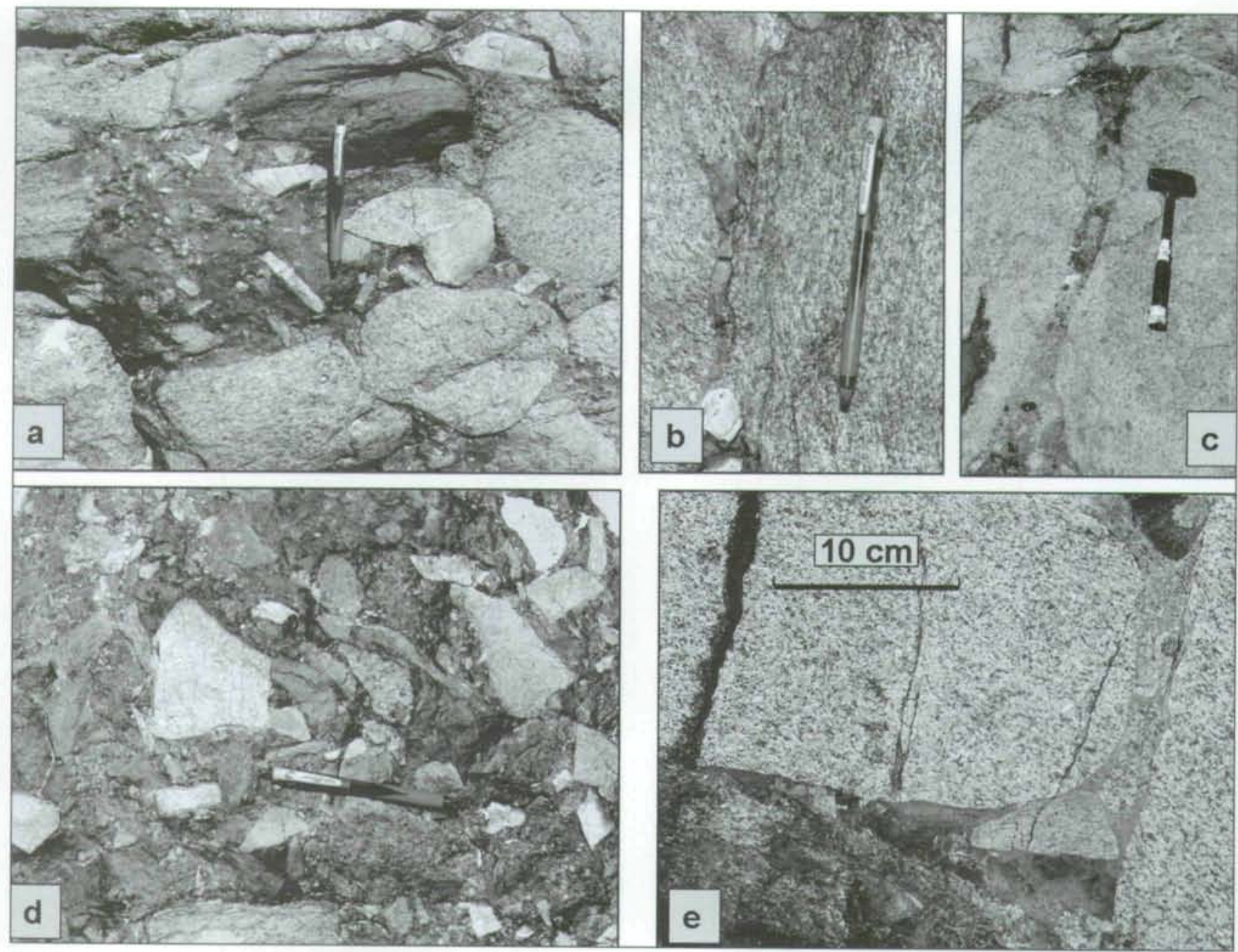

Figure 13. (a) Highly angular, tabular granite clasts in chloritized matrix pod surrounded by larger and more rounded clasts, (b) "Vein" of chloritized mass trapped between two granitic gneiss blocks, together with a white clast of granitic leucogneiss (lower left). (c) Cbloritized vein containing numerous matrix breccia clasts between two blocks of granitoid gneiss. (d) Close-up of a patch of matrix breccia containing angular granitic clasts and deformed shard-like chlorite-rich fragments that indicate that they were not rigid at the time of breccia formation. (e) Dark, fine-grained, clast-poor vein enclosing small litbic clasts and wedged between larger granitic clasts.

In general, circular structural patterns are attributed to either magmatic or salt diapirs, fold interference patterns, or to impacts. Diapiric magmatic bodies are a feature of some Archaean granite-greenstone terranes (e.g., Barberton), but investigations have failed to show such features or any large-scale interference folding in the Kraaipan region (Anhaeusser, 1991). Conversely, despite an active search, no unequivocal impactdiagnostic features have been found within the area covered by the magnetic anomaly - not only have no impact breccias been found within the limits of the anomaly, but the exposed basement rocks show no outcrop-scale or microscopic shock deformation features. They do, however, display abundant intersecting fracture sets and mylonitic shears (Figure 7).

If the anomaly does reflect an impact structure, the absence of crater-fill breccias would require substantial erosion (at least several hundred metres for a crater up to 25 to $30 \mathrm{~km}$ wide). However, as studies in other exhumed impact structures have shown (e.g., Gibson and Reimold, 2005), significantly more erosion would be needed to remove all traces of the shock effects in the crater basement. In the event that strongly differential erosion is not possible (given that surface-formed breccias of apparently the same age are preserved nearby at Setlagole), the absence of shock-diagnostic features might be construed as evidence for a nonimpact origin for the structure. However, the absence of evidence of such features between Setlagole and Madibogo may also reflect the lack of exposure of the central parts of the anomaly. Mapping and modeling of complex impact structures shows that shock metamorphism is largely restricted to the central uplift volume (e.g., Therriault et al., 1997a; Gibson and Reimold, 2005; Ivanov, 2005). Assuming a central uplift diameter of $\sim 7 \mathrm{~km}$ (a diameter corresponding to the central circular anomaly in Figure 5 and which would be consistent with a crater diameter of 25 to $30 \mathrm{~km}$ Melosh, 1989; Grieve, 1997), would place known stream outcrops between Setlagole and Madibogo (Figure 1b) 

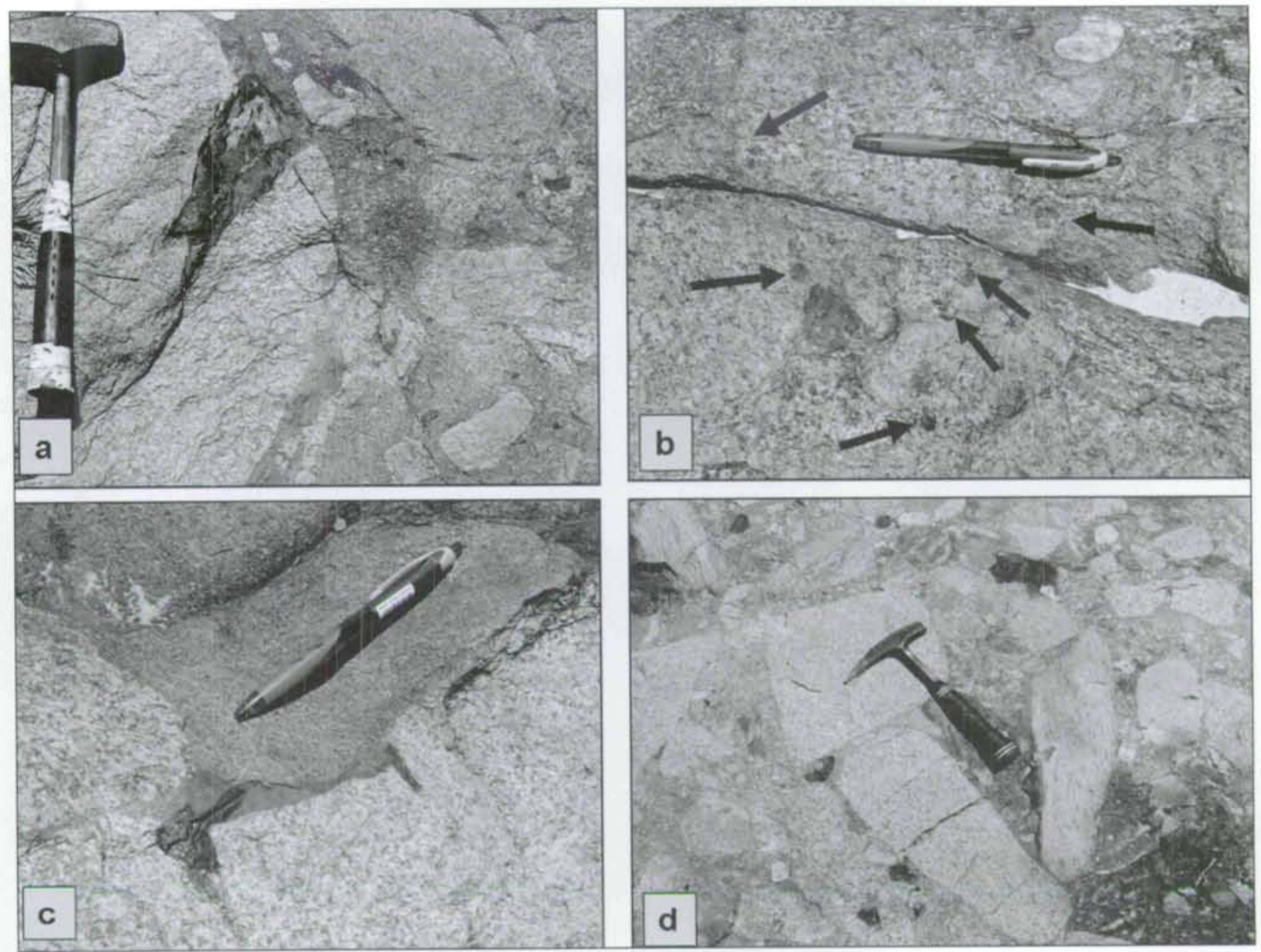

Figure 14. Morphology of 'dark clasts' and related cbloritized masses in the Setlagole megabreccia. (a) Dark chloritized mass witb small granitic fragments wedged between larger granitic blocks. Note the contrast with the sandy matrix in the rest of the photograph. (b) Granitic breccia clasts and matrix breccia containing numerous, randomly scattered, centimetre-sized dark clasts (arroued). (c) Dark, fine-grained and clast-poor chloritized mass at the interface between sandy breccia matrix (beneath pen) and granite clast. This mass penetrates into the granite clast along fractures, whicb contain cbloritized veins resembling pseudotacbylite (see text). (d) Scattered, irregular-shaped, dark clasts in matrix surrounding larger angular and rounded granite and granitoid gneiss clasts. A clast-rich patcb of dark matrix breccia is evident in the louver right of the photograph.

on the extreme western edge of this 'central uplift'. Based on shock patterns in other exhumed central uplifts, such as the Vredefort Dome (Therriault et al., 1997a; Gibson and Reimold, 2005), the outer parts of the central uplift would have likely experienced shock pressures below that required to form PDFs in quartz. Under these low-shock conditions only shatter cones might be expected to form; however, coarse-grained igneous rocks are generally not conducive to the development of shatter cones (French, 1998). If the impact structure was smaller, then not only is less erosion needed to remove the crater-fill breccias, but the zone of possible shock metamorphic effects is also reduced.

\section{Origin of the Setlagole breccia}

The two breccia outcrops near Setlagole lie close to, but outside of, the northern margin of the magnetic anomaly
(Figures 1 and 2). Whether this margin actually corresponds to the edge of the structure is not clear; nonetheless, the age constraints on the breccia and the Setlagole structure suggest that there is a good chance that they could be related. In such a case, impact would be the strongest candidate to explain both features. An hypothesis that links the formation of the magnetic anomaly to that of the breccias would then require an explanation of how the breccias, which formed at the surface, can have been preferentially preserved from erosion when any interpretation of the circular feature to the south as an impact structure requires that it has subsequently been significantly eroded. Such an explanation may be provided by the east-northesterlytrending magnetic lineament lying south of Setlagole (dotted line in Figure 5). This lineament lies parallel to a set of major tectonic features that transect the Kaapvaal Craton, including the Thabazimbi-Murchison Lineament 

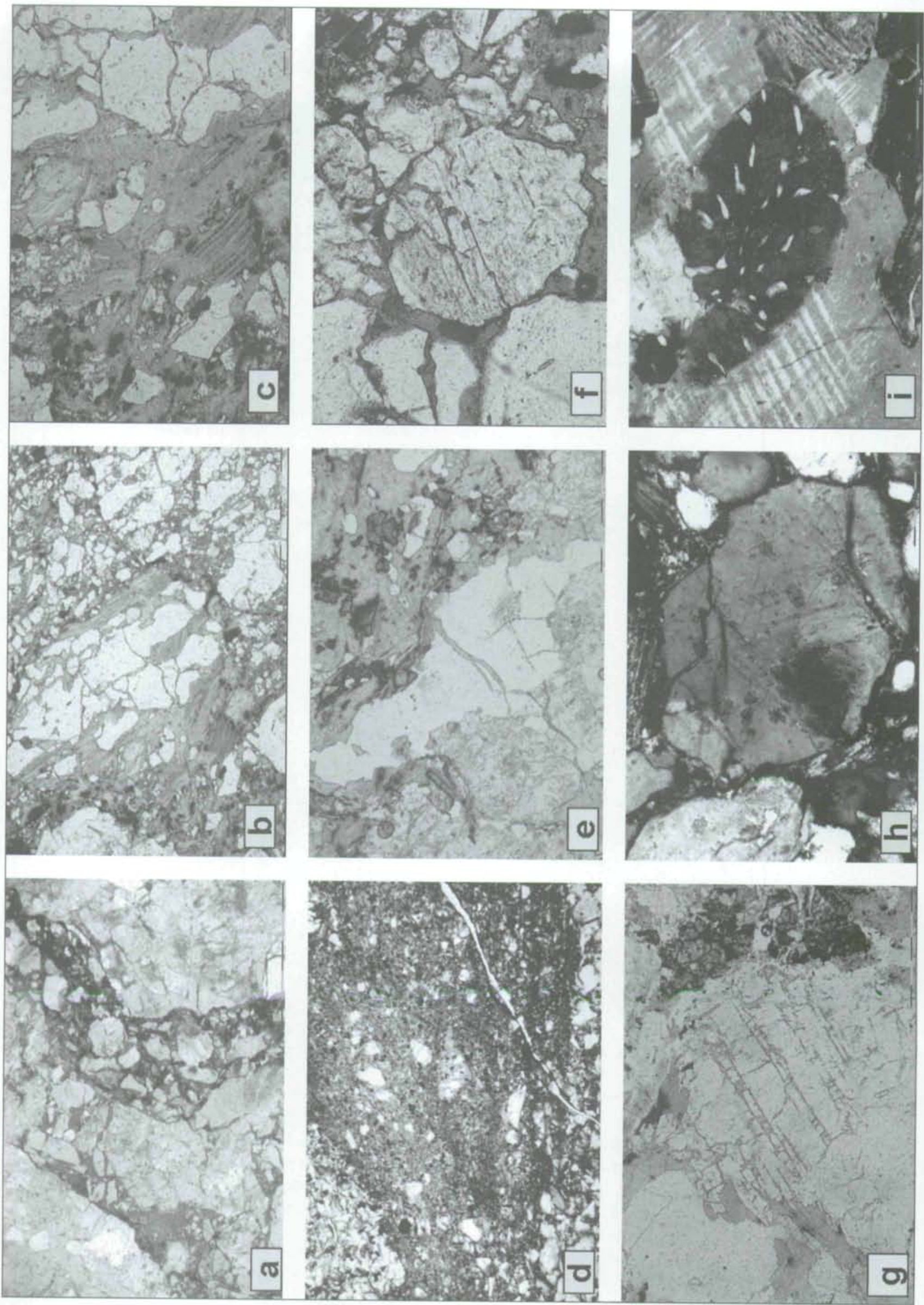
Figure 15. Pbotomicrographs of Setlagole breccia. (a) Dark, cblorite-rich, microbreccia tein containing litbic and mineral clasts (scale bar $5 \mathrm{~mm}$ ). (b) Microbreccia showing cbloritic matrix and evidence for in-situ cbloritization (scale bar 500 um). (c) Close-up of (b) sbouting cblorite mass replacing biotite (louver centre left, upper centre right; scale bar 500 um). (d) Dark clast shouing fine-grained, more cbloriterich matrix relative to the sandy matrix (top left and bottom). Note that the clast itself contains abundant angular quartz and feldspar mineral fragments (field of view $3 \mathrm{~mm}$ wide). (e) Quartz-feldspar clast flanked by cbloritized breccia matrix. Chlorite from the matrix penetrates into the quartz as micro-veins (scale bar $1 \mathrm{~mm})$. ( $f$ Mineral clasts embedded in chlorite matrix and shouing evidence for in-situ brecciation (main clast, centre - scale bar $500 \mu \mathrm{m}$ ). (g) Plagioclase clast showing alteration along tuin planes, Darker mass to rigbt is epidote (scale bar $500 \mu \mathrm{m}$ ). (b) Quartz clast sbowing two sets of planar fluid inclusion trails, patcby extinction and irregular fractures that locally sbow subgrain development (scale bar $200 \mu \mathrm{m}$ ). It is argued tbat metamorphism could bave annealed (and bence obliterated) possible PDF microstructures that may originally bave been present in the breccia. (i) Quartz-plagioclase myrmekite in microcline micropertbite (scale bar $500 \mu \mathrm{m}$ ). All images plane-polarized light except (b) and (i) wbicb are crossed-polar images.

- a dominant structural feature in the Kaapvaal Craton that records repeated, and significant, tectonic movement from Archaean times onwards. Whilst the magnetic lineament may be defined by an unexposed dyke intrusion, field evidence in support of faulting is present in the form of broadly easterly-trending breccia and fracture zones in the basement rocks south of Setlagole (Figure 7) that parallel the major lineament orientation. We would propose, thus, that the oldest lineament cutting the anomaly accommodates fault movement, and that significant downthrow to the north along this and related smaller faults could have led to the preservation of the Setlagole breccia while the areas to the south underwent erosion. The fact that similar east-trending fractures cut the Setlagole breccia itself indicates that brittle deformation did postdate breccia formation. Block rotation associated with such faulting could also potentially account for the gentle northeasterly dip of the layering in the breccia.

In order to evaluate whether the Setlagole breccia could be an impact-related deposit, it is necessary to consider alternative hypotheses. The absence of volcanic clasts in the breccia makes a volcanic origin either from explosive volcanism or debris flows of volcanic origin - highly unlikely.

Given the earlier statement that the breccia may be preserved as a result of faulting, it is necessary to consider whether it could have been produced in such a manner. Du Toit (1906) originally suggested that the Setlagole breccia marked a thrust fault. However, the absence of evidence of slip along the basal contact of the breccia at Locality 1 , or other kinematic indicators, together with the clear evidence of fluvial depositional features (Figures 12a and c), precludes such a mechanism.

Fault-scarp breccias have been described by Winter (1965; 1976), in the Kameeldoorns Formation near the base of the Platberg Group (upper Ventersdorp Supergroup) in the Bothaville region, approximately $200 \mathrm{~km}$ southeast of Setlagole. Keyser (1998) indicated that similar features have not been found in the areas to the west. Volcanic debris, described by Von Backström (1952) in the area north and south of Ottosdal, approximately $100 \mathrm{~km}$ southeast of Setlagole, and by Winter (1976) and Keyser (1998) in the Vryburg-
Ottosdal-Mafikeng region, are referred to as volcanic conglomerates, agglomerates and tuffs, pyroclastic flows, and pyroclastic surges. These rocks have significantly smaller clast sizes than the Setlagole breccia and include Ventersdorp lava clasts and fragments of coarse-grained, reddish, microcline granite (north of Ottosdal), both of which are not seen in the Setlagole breccia.

A breccia, which may be related to a fault scarp, occurs immediately south of Stella, some $40 \mathrm{~km}$ southwest of Setlagole (Anhaeusser, 1991; Keyser, 1998). The breccia comprises fragments of Kraaipan ironformation of the Gold Ridge Formation, but contains no granitic clasts and is also devoid of the distinctive 'pseudotachylitic' matrix found in the Setlagole megabreccia.

Avalanche or scree deposits, whilst capable of producing similar clast size distributions to those seen in the Setlagole breccia, cannot explain the presence of graded bedding and water deposition features and would require an unusual preservation mechanism, such as fault downthrow, to remove the extreme topography, but not the breccia.

Glacial deposits are known from a variety of settings and ages in southern Africa, including the Mesoarchaean (ca $2.9 \mathrm{Ga}$ ) Government Subgroup of the lower Witwatersrand Supergroup. Unlike the Setlagole breccia, the Government Subgroup diamictites lack layering and are matrix-supported, with only limited numbers of large clasts. These are generally in the centimeter to decimeter size range and a significant number display glaciallygenerated striations (Camden-Smith, 1980; Reimold et al., 1997). As lower Witwatersrand Supergroup rocks are known to occur over a wider region than in the Witwatersrand basin $150 \mathrm{~km}$ southeast of Setlagole, the possibility that the Setlagole breccia represents a fluvial-glacial outwash-deposit related to one of these glacial events should be considered. However, the lack of evidence of striated clasts seems problematic, given the abundance of clasts in the breccia. Present constraints on the age of the Kraaipan metamorphic peak preclude the breccia being older than $2.79 \mathrm{Ga}$.

Earthquake-triggered tsunami deposits of varying sizes and extents are known from numerous coastal regions around the world (e.g., Goto et al., 2005). 

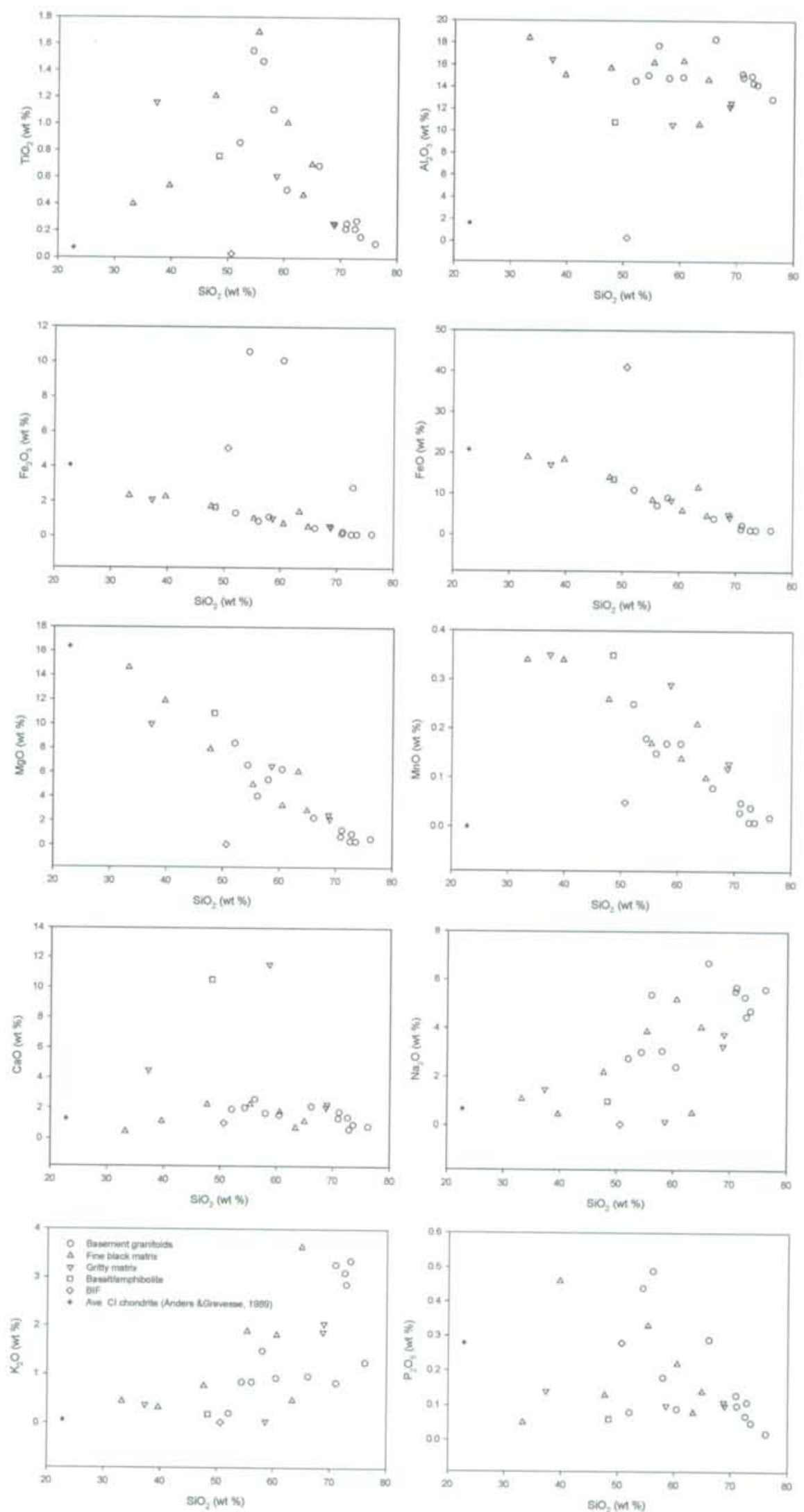

Figure 16. Harker plots for major elements in the Setlagole megabreccia. Symbols used in the diagrams are shoun in the $\mathrm{SiO}_{2}$ es. $\mathrm{K}_{2} \mathrm{O}$ plot. 

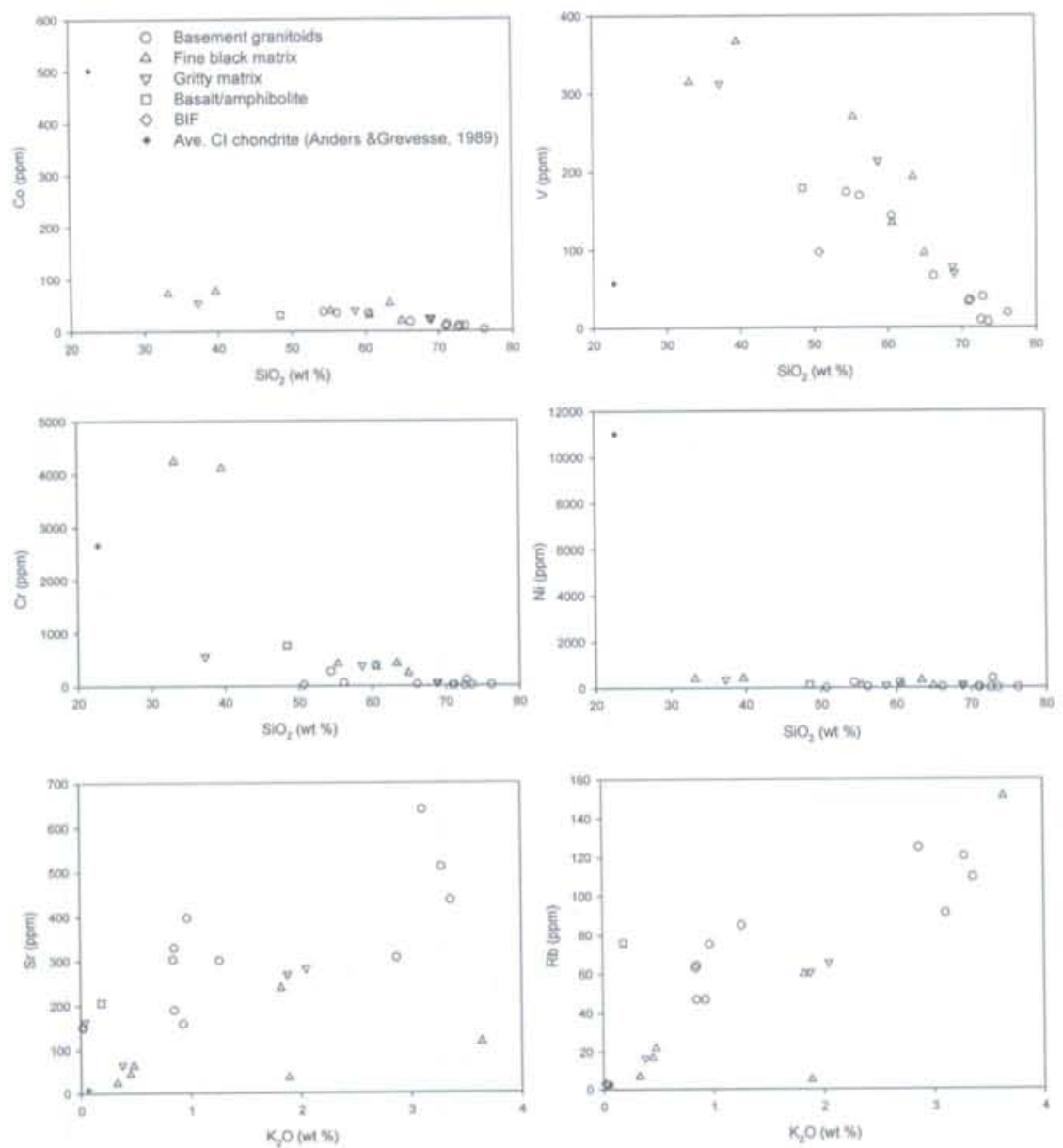

Figure 17. Harker plots for selected trace elements in the Setlagole megabreccia. Symbols used in the diagrams are shoun in tbe $\mathrm{SiO}_{2}$ es, Coplot.

However, tsunamis could also be triggered by marine impacts. Tsunamis are characterised by highly variable depositional energies that change rapidly, allowing vastly different fragment sizes to be deposited in close proximity in rapid succession. Importantly, though, the nature of the debris is dependent on the pre-tsunami environment. For instance, large boulders are unlikely to be found in moderately deep water marine settings because of a lack of a mechanism to get them there in the first place. The parochial nature of the clasts in the Setlagole breccia suggests that the depositional mechanism would not have had to move the large fragments very far. The bulk of the matrix fraction also appears to comprise lithic and sand-sized mineral fragments of local derivation. There is also some evidence, in the form of flow structures, to suggest that the sandy matrix and finer clast fraction settled gravitationally into spaces between the larger clasts. Whilst a shoreline tsunami would be capable of both piling up large locally-derived boulders into deposits several metres high and, virtually simultaneously, depositing massive amounts of sand and finer particles on top of such a boulder deposit, the apparently unstable orientation of some boulders in matrixsupported regions of the breccia suggests concomitant deposition of the boulders and sandy matrix.

As a general mechanism, a debris flow provides the most reasonable explanation for most of the features seen in the Setlagole breccia. Given sufficient initial momentum, such flows are known to be capable of traveling tens of kilometres over relatively flat terrain, which would negate the need for significant topographic relief in close proximity to the Setlagole breccia localities. The slurry of water and fine debris also provides an effective medium in which to support and move extremely large clasts. Debris flows may also include planar fluvial-type deposits where water volumes are sufficiently high, and later surges within the flow could potentially deposit coarse breccias overlying sandy, fluvially-deposited layers, as would be required to explain the layering sequence at Locality 2 . What is not apparent is the event responsible for such a flow. 


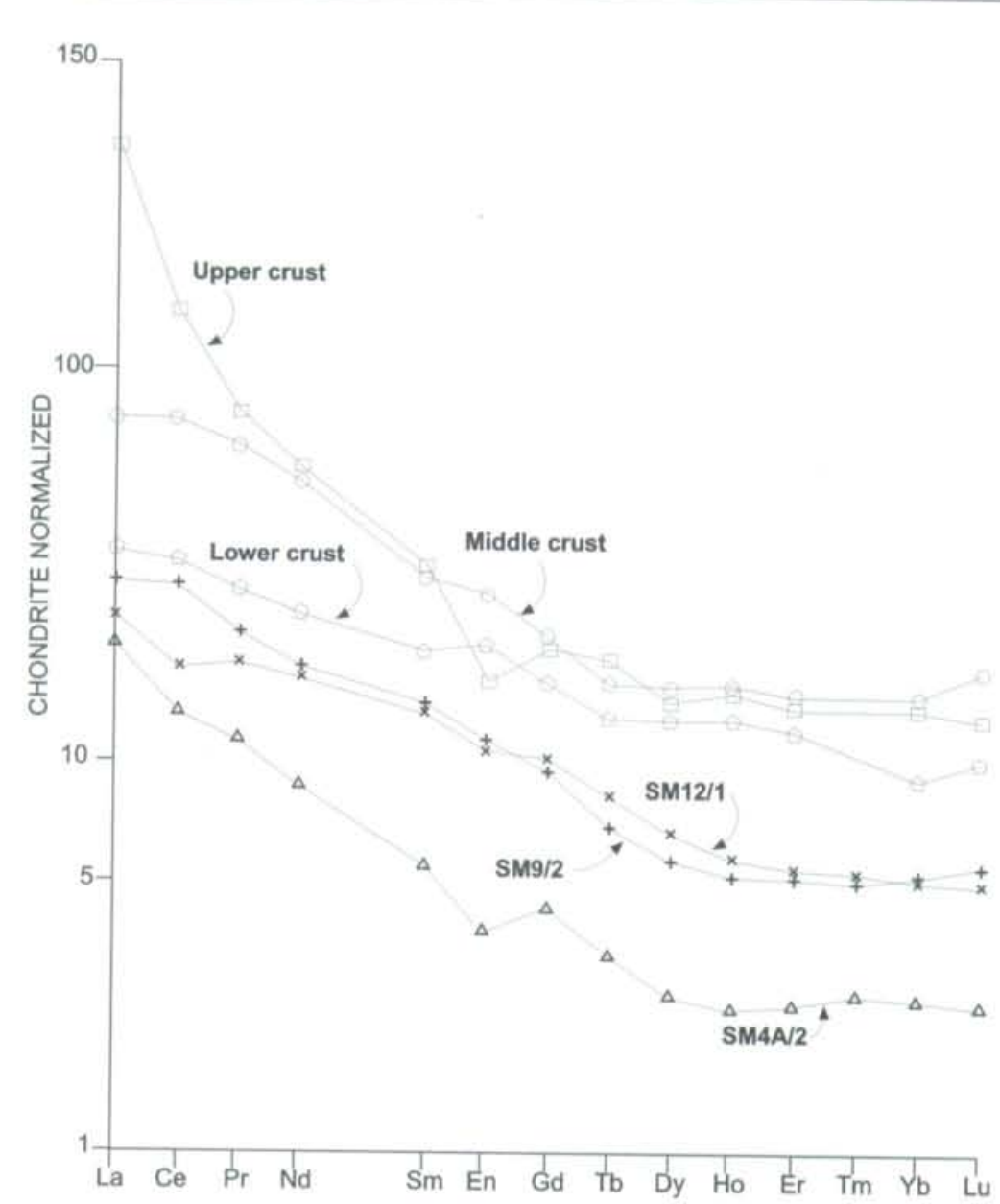

Figure 18. REE patterns of selected samples of dark, fine-grained and clast-poor cbloritized masses in the megabreccia that might represent chloritized mud clasts or impact melt clasts. The Setlagole samples (lower three on diagram) are compared to REE patterns of average upper, middle and lower crustal talues (after Taylor and McLennan, 1985; 1995 and Rudnick and Fountain, 1995).

Debris flows are capable of forming simply in regions of high relief where weathered slopes become watersaturated during heavy rainfall or snow melt, but could also form during fault-related uplift or earthquake activity and in impact craters where sudden changes in slope around the central uplift or crater rim create similar effects. In marine settings, craters may also be subjected to resurge effects that avalanche debris created by the impact back into the crater (e.g., Dypvik and Kalleson, 2008; Ormö et al 2010). In a highly degraded area such as Setlagole, evidence of unusually high strainrate and shock deformation in the lithic and mineral clasts in the breccia becomes crucial to establishing an impact connection. Studies in other craters suggest that the proportion of shocked material can vary drastically, particularly where an abundant sediment supply already exists in the target (such as in the Chesapeake Bay structure; Horton et al., 2005). The presence in the Setlagole breccia of rare breccias resembling pseudotachylite within clasts, and the resemblance of these to more abundant dark fluidal-textured clasts in the breccia, raises the possibility of these being melts. Unfortunately, the metamorphic alteration has extensively modified the original character of these fragments. Given the proximity to the circular magnetic anomaly, future high-precison geochemical and microtextural analysis is warranted.

\section{Conclusions}

Breccia outcrops near Setlagole village in northwestern South Africa occur on the periphery of a 25 to $30 \mathrm{~km}$ wide circular structure defined using aeromagnetic data, and appear to share a similar Mesoarchaean age with the structure. The origins of both the breccia and the structure remain enigmatic. No breccias have been found within the perimeter of the structure, which would indicate that significant erosion has occurred if it was of impact origin. No shock deformation features have been found in the Archaean granites and gneisses, but outcrop is poor and is completely lacking in the central parts of the structure. The breccia displays a generally massive, chaotic structure consistent with a 
debris flow; however, at least one sandy layer within its upper parts indicates some fluvial component to deposition. No conclusive shock-deformed particles have been found within the breccia; however, enigmatic irregular, fluidal-textured clasts that are strikingly similar to pseudotachylitic breccia veins in one of the clasts raise questions about whether the breccia can be the result of normal mass-wasting processes. It is proposed that the breccia may reflect a deposit generated by tsunami or resurge action, or near-rim avalanche processes, associated with a marine impact cratering event. If confirmed by further geochemical and petrographic work, the Setlagole structure may arguably be the oldest impact structure on Earth.

\section{Acknowledgements}

Helpful discussions were held with Dr Marco Andreoli on the geology of the Morokweng-Setlagole area and with Professors Grant Cawthorn and Lew Ashwal on aspects of the unusual geochemistry encountered in the megabreccia matrix. Grant Bybee assisted with the processing of the geochemical data and figure layout, and Dianne du Toit and Lynda Whitfield assisted with drafting. Jörg Fritz, Herbert Henkel and Uwe Reimold offered useful comments and criticisms in reviews of an earlier version of the paper. CRA acknowledges support grants from the Science Faculty Research Committee (FRC) and from the School of Geosciences, University of the Witwatersrand.

\section{References}

Andreoli, M.A.G., Hart, R.J., Cooper, G.R.J., Stengel, I., Webb, S., Haddon, I., Skăla. R. and Viola, G., 2008a. Morokweng: $>100 \mathrm{~km}$ and still growing. Geobulletin Geological Society of South Africa, 51(1), 12-15.

Andreoli, M.A.G., Hart, R.J., Cooper, G.R.J. and Webb, SJ., 2008b, The Morokweng impact crater, South Africa: A complex, multiring structure with a $-130 \mathrm{~km}$ radius external ring and asymmetric radial sectors. Abstract, Large Meteorite Impacts and Planetary Ẽvolution IV, Lunar and Planctary Institute (LP) Contribution No. 1423, 29-30.

Anhaeusser, C.R., (Editor), 1991. The Archaean Kraaipan Group VolcanoSedimentary Rocks and Associated Granites and Gneisses of the Southwestern Transvaal, Northwestern Cape Province and Bophuthatswana. Excursion Guidebook, 1991 Geological Society of South Africa Summer Field School, Department of Geology, University of the Witwatersrand, Johannesburg, 45pp.

Anhacusser, C.R and Walraven, F., 1999. Episodic granitoid emplacement in the western Kaapvaal Craton: Evidence from the Kraaipan granitegreenstone terrane, South Africa. Journal of African Earth Science, 28, 289-309.

Armstrong, R.A., 1987. Geochronological studies on Archaean and Proterozoic formations of the foreland of the Namaqua Front and possible correlates on the Kaapvaal Craton. Unpublished Ph.D. thesis, University of the Witwatersrand, Johannesburg, South Africa, 274pp.

Armstrong. R.A., Compston, W., Retief, E.A., Williams, I.S. and Welke, H.J., 1991. Zircon ion microprobe studies bearing on the age and evolution of the Witwatersrand Triad. Precambrian Research, 53, 243-266.

Brandl, G., Cloete, M., and Anhaeusser, C.R., 2006. Archaean greenstone belts, In: M. R. Johnson, C. R. Anhaeusser, and R. J Thomas (Editors), The Geology of South Africa, Geological Society of South Africa/Council for Geoscience, 9-56.

Camden-Smith, P.M., 1980. The sedimentology, geochemistry and diagenesis of the West Rand Group sediments in the Heidelberg area, Transvaal. Unpublished M. Sc. thesis, University of Cape Town, Cape Town, South Africa, 96pp.
Collins, L.G., 1997. Contrasting characteristics of magmatic and metasomatic granites and the myth that granite plutons can be only magmatic. ISSN 1526-5757 Electronic Internet Publication, No 39.

Cooper, G.R.J., 2003. Feature detection using sun shading. Computers and Geosciences, 29, 941-948.

Cooper, G.R.J., Webb, S.J., Gibson, R.L. and Martinez, I., 2010. A possible new impact structure in the Okavango Delta, Botswana. In: R.L Gibson, and W.U. Reimold (Editors), Large Meteorite Impacts and Planetary Evolution IV: Geological Society of America Special Paper 465, 191-199, doi: $10.1130 / 2010.2465(13)$.

Corner, B., 2008. Crustal framework of Namibia derived from an integrated interpretation of geophysical and geological data. In; R. McG. Miller, The Geology of Namibia, Vol. 1, Archaean to Mesoproterozoic: Geological Survey of Namibia, Windhoek, 2-1 to 2-19.

Comer, B., Reimold, W.U., Brandt, D. and Koeberl, C, 1997. Morokweng impact structure, Northwest Province, South Africa: Geophysical imaging and shock petrographic studies. Earth Planetary Science Letters, 146, 351-364.

Cornell, D.H., 1978. Petrologic studies at TKuip: Evidence of metamorphism and alteration of volcanic formations beneath the Transvaal volcanosedimentary pile. Transactions of the Geological Society of South Africa, 81, 261-270.

Cornell, D.H., Armstrong, R.A. and Walraven, F., 1998, Geochronology of the Hartley Formation, South Africa: Constraints on the Kheis tectogenesis and the Kaapvaal Craton's earliest Wilson Cycle, Journal of African Earth Science, 26, 5-27.

Council for Geoscience, 1997. 1: 1000000 Magnetic Fabric Map of the Republic of South Africa: Geophysical Division, Council for Geoscience, Pretoria.

Cowan, D.R. and Cooper, G.R.1., 2005. Enhancement of magnetic signatures of impact structures, In: T. Kenkman, F. Horz, and A. Deutsch (Editors), Large Meteorite Impacts III: Geological Society of America Special Paper, 384, 51-65.

Duncan, A.R. and Marsh, J.S., 2006. The Karoo Igneous Province. In: M.R. Johnson, C.R. Anhaeusser, and R.J. Thomas (Editors), The Geology of South Africa. Geological Society of South Africa/Council for Geoscience, 501-520

Du Toit, A.1. 1906. Geological survey of portions of the divisions of Vryburg and Mafeking. Annual Report of the Geological Commission of the Cape of Good Hope (1905), 205-258.

Dypvik, H. and Kalleson, E., 2008. Marine impacts - mechanisms of early post-impact crater sedimentation. Abstract, Large Meteorite Impacts and Planetary Evolution IV, Lunar and Planetary Institute Contribution No. 1423, 66pp.

Eriksson, P.G., Altermann, W. and Hartzer, FJ., 2006. The Transvaal Supergroup and its precursors. In: M.R. Johnson, C.R. Anhueusser and R. J. Thomas (Editors), The Geology of South Africa. Geological Society of South Africa/Council for Geoscience, 237-260.

French, B.M., 1998, Traces of Catastrophe. Lunar and Planetary Institute Contribution No. 954, Lunar and Planetary Institute, Houston, Texas, $120 \mathrm{pp}$.

Garwin, J.B., Schnetzler, C. and Grieve, A.F., 1992. Characteristics of large terrestrial impact structures as revealed by remote sensing studies. Tectonophysics, 216, 45-62.

Gibson, R.L. and Reimold, W.U., 2005. Shock pressure distribution in the Vredefort impact structure, South Africa. In: T. Kenkmann, F. Hörz, and A. Deutsch (Editors), large Meteorite Impacts and Planetary Evolution III. Geological Society of America Special Paper, 384, 329-349.

Gibson, R.L. and Reimold, W.U., 2008. Geology of the Vredefort Impact Structure: A Guide to Sites of Interest. Memoir, Council for Geoscience, Pretoria, 97, 181pp.

Goto, K., Tajika, E., Tada, R, and Matsui, T., 2004. Formation of a large oceanic impact crater and generation of impact tsunamis at the Cretaceous/Tentiary boundary. Journal of Japan Society for Planetary Sciences, 13, 241-248

Grieve, A.F., 1987. Terrestrial impact structures, Annual Review of Earth and Planetary Sciences, 15, 245-270.

Grieve, R.A.F., Coderre, J.M., Robertson, P.B. and Alexopoulos, J., 1990. Microscopic planar deformation features in quarz of the Vredefor structure: Anomalous but still suggestive of an impact origin. Tectonophysics, $171,185-200$ 
Harmer, R.E., 1992, The geochemistry of Spitskop and related alkaline complexes. Unpublished Ph. D. thesis; University of Cape Town, South Africa, 287pp.

Hart, R.J., Andreoli, M.A G., Tredoux, M., Moser, D., Ashwal, L.D., Eide, E.A., Webb, S., and Brandt, D., 1997, Late Jurassic age for the Morokweng impact structure, southern Africa. Earth Planetary Science Letters. $147,25-35$

Hirner, A., J., 2001. Geology and gold mineralization of the Madibe greenstone belt, eastern part of the Kraaipan Terrain, Kaapvaal Craton, South Africa: Unpublished Ph. D. thesis, University of the Witwatersrand, Johannesburg, South Africa, 453pp

Horton, J.W., Jr. and Izett, G.A., 2005. Crystalline-rock ejecta and shocked minerals of the Chesapeake Bay impact structure, USGS-NASA Langley core, Hampton, Virginia, with supplemental constraints on the age of impact., In: J.W., Horton, Jr., D. S Powars, and G.S., Gohn, (Editors), Studies of the Chesapeake Bay impact structure - The USGS-NASA Langley corchole, Hampton, Virginia, and related coreholes and geophysical surveys. U. S. Geological Survey Professional Paper 1688, Chapter E. E1-E30.

Kalleson, E. and Dypvik, H., 2008. The Gardnos structure - preservation and exposure of an old impact crater. Poster, Conference on Large Meteorite Impacts and Planetary Evolution IV, Vredefort Dome, South Africa, 17-21 August 2003.

Keyser, N., 1998. The geology and geochemistry of the Ventersdorp Supergroup in the area between Vryburg, Ottosdal and Mafikeng. Geological Survey of South Africa Bulletin, 122, 117pp.

Khirfan, M., Kenkmann, T., Salameh, E., Omary, Y., and Reimold, W.U., 2008. Remote sensing and structural analysis of Jabal Waqf As Suwwar meteorite impact, Abstract, Large Meteorite Impacts and Planetary Evolution IV, Lunar and Planetary Institute Contribution No, 1423 114-115.

Melosh, H.J., 1989. Impact Cratering: A Geologic Process. Oxford University Press, New York, U.S.A., 245pp

Miller, H.G. and Singh, V., 1994. Potential field tilt - a new concept for location of potential field sources. Journal of Applied Geophysics, $32,213-217$

Miyano, T. and Beukes, N.J., 1984. Phase relations of stilpnomelane, ferriannite, and riebeckite in very low-grade metamorphosed iron-formations Transactions of the Geological Society of South Africa, 87, 111-124.

Moen, H.F.G., 2006. The Olifantshoek Supergroup. In: M.R. Johnson, C.R. Anhaeusser, and RJ. Thomas (Editors). The Geology of South Africa. Geological Society of South Africa/Council for Geoscience, 319-324.

Ormö. J., Lepinette, A., Sturkell, E., Lindström, M., Housen, K.R. and Holsapple, K.A., 2009. The water resurge at marine-target impact craters analyzed with a combination of low-velocity impact experiments and numerical simulation. In: R.L. Gibson, and W. U. Reimold (Editors), Large Meteorite Impacts IV, Geological Society of America Special Paper, 465, 81-101, doi: 10,1130/2010.2465 (13).

Poujol, M., Anhaeusser, C.R. and Armstrong, R.A., 2002. Episodic granitoid emplacement in the Archaean Amalia-Kraaipan terrane, South Africa: Confirmation from single zircon U-Pb geochronology. Journal of African Earth Science, 35, 147-161.

Poojol, M., Robb, LJ, Anhaeusser, C.R, and Gericke, B., 2003. A review of the geochronological constraints on the evolution of the Kaapvaal Craton, South Africa. Precambrian Research, 127, 181-213.

Prinz, T., 2009. (Gosses_Bluff/Bluff.html), Multispectral remote sensing of the Gosses Bluff impact structure. Central Australia, by using Landsat-TM and ERS-1 data. Retrieved on 12-01-2009 from www.uni Muenster.de/GeoPalaeontologie/Geologie/Ferngis/Gosses_Bluff/ Bluff.html.

Reed, M.D.P., 1996. 1:1 000000 total field aeromagnetic grid of the southern African region. Kaapvaal Craton Study, Southern African Seismic Experiment, Anglo American Corporation Geophysical Services Department.

Reimold, W.U., 2006. Impact structures in South Africa, In: M.R. Johnson, C.R. Anhaeusser, and R.J, Thomas (Editors). The Geology of South Africa. Geological Society of South Africa/Council for Geoscience, 629-649.

Reimold, W. U. and Gibson, R. L., 2005. Meteorite Impact The danger from space and South Africa's mega-impact the Vredefort Structure. Chris van
Rensburg Publications and the Council for Geoscience, Pretoria, 319pp. Reimold, W.U., Horsch, M. and Durrheim, R.J., 1990. The 'Bronzite'Granophyre from the Vredefort Structure - a detailed analytical study and reflections on the origin of one of Vredefort's enigmas. Proceedings of the 20th Lunar and Planetary Science Conference, Lunar and Planetary Institute, Houston, 433-450.

Reimold, W.U., von Brunn, V. and Koeberl, C., 1997. Are diamictites impact ejecta? - No evidence from South African occurrences, Journal of Geology, $105,517-530$

Robb, L.J., Brandl, G., Anhaeusser, C.R. and Poujol, M., 2006, Archaean granitoid intrusions of the Kaapvaal Craton. In: M.R. Johnson, C.R. Anhaeusser, and R.J. Thomas (Editors), The Geology of South Africa. Geological Society of South Africa/Council for Geoscience, 57-94.

Rudnick, R.L, and Fountain, D.M., 1995. Nature and composition of the continental crust: A lower crustal perspective, Reviews of Geophysics, 33, 267-309.

SACS: South African Committee for Stratigraphy, 1980. Stratigraphy of South Africa. Part 1 (Kent, L. E. Compiler), Lithostratigraphy of the Republic of South Africa, South West Africa/Namibia and the Republics of Bophuthatswana, Transkei and Venda. Geological Survey of South Africa Handbook, 8, 690pp.

Schmitz, M.D., Bowring, S.A., De Wit, M.J. and Gartz, V., 2004. Subduction and terrane collision stabilize the western Kaapvaal Craton tectosphere 2.9 billion years ago. Farth and Planetary Science Letters, 222, 363-376.

Sivell, W. and Rankin, P., 1983. Arc-tholeite and ultramafic cumulate, Brook Street Volcanics, west DUrville 1sland, New Zealand. New Zealand Journal of Geology and Geophysics, 26, 239-257.

Taylor, S.R. and Mclennan, S.M., 1985. The continental crust: Its composition and evolution. Blackwell, Oxford, 312pp.

Taylor, S.R. and McLennan, S.M., 1995. The geochemical evolution of the continental crust. Reviews of Geophysics, 33, 241-265.

Therriault, A.N., Reid, A.M. and Reimold, W.U., 1997a. Original size of the Vredefort Structure, South Africa, Meteoritics and Planetary Science. $32,71-77$

Therriault, A.N., Reimold, W.U. and Reid, A.M., 1997b. Geochemistry and impact origin of the Vredefort Granophyre. South African Journal of Geology, 100, 115-122.

Van der Westhuizen, W.A., De Bruiyn, H. and Meintjes, P.G., 2006. The Ventersdorp Supergroup. In: M.R. Johnson, C.R. Anhaeusser, and R.J. Thomas (Editors), The Geology of South Africa. Geological Society of South Africa/Council for Geoscience, 187-208.

Van Niekerk, C.B., 1962. The age of the Gemspost Dyke from the Venterpost Gold Mine. Transactions of the Geological Society of South Africa, 65, 105-111.

Von Backstrom, JW, 1952. The Dominion Reef and Witwatersrand Systems between Wolmaransstad and Otosdal, Transvaal. Transactions of the Geological Society of South Africa, 55, 53-71.

Verwoerd, WJ., 2006. The Pilanesberg Alkaline Province. In: M.R. Johnson, C.R. Anhaeusser, and R.J. Thomas (Editors), The Geology of South Africa. Geological Society of South Africa/Council for Geoscience, 381-393.

Walraven, F., Armstrong, R.A. and Kruger, FJ., 1990. A chronostratigraphic framework for the north-central Kaapvaal Craton, the Bushveld Complex and Vredefort structure. Tectonophysics, 171, 23-18.

Walraven, E. and Hattingh, E., 1993. Geochronology of the Nebo Granite; Bushveld Complex. South African Journal of Geology, 96, 31-41.

White, W.M., 2001. Geochemistry - Part 2: Understanding the Earth. http:/www.geo.cornell.edu/geology/classes/geo 455/ chapters.html

Winter, H. de la R., 1965. The stratigraphy of the Ventersdorp System in the Bothaville District and adjoining areas. Unpublished $\mathrm{Ph}, \mathrm{D}$, thesis, University of the Witwatersrand, Johannesburg, South Africa, 130pp.

Winter, H. de la R., 1976. A lithostratigraphic classification of the Ventersdorp succession. Transactions of the Geological Society of South Africa, $79,31-\mathbf{i} 8$.

Zimmermann, O.T. (1994). Aspects of the geology of the Kraaipan Group in the Northern Cape Province and the Republic of Bophuthatswana. Unpublished M.Sc. thesis, University of the Witwaterstand, Johannesburg. South Africa, $145 \mathrm{pp}$.

Editorial handling: J. M. Barton Jr. 
Copyright of South African Journal of Geology is the property of Geological Society of South Africa and its content may not be copied or emailed to multiple sites or posted to a listserv without the copyright holder's express written permission. However, users may print, download, or email articles for individual use. 